\title{
SZUNOMÁR ÁGNES
}

\section{A digitális nagy ugrás}

\section{Lassulás és modernizációs stratégiaváltás Kínában}

\begin{abstract}
A digitalizáció napjainkra a kínai gazdaság fejlesztésének, modernizációjának kulcsterületévé vált. Jelen írás e kínai „digitális nagy ugrás”, azaz a korábbi modernizációs pálya radikális átalakításának esélyeit elemzi. Az irodalom szisztematikus áttekintése alapján a szerző összegyủjti, bemutatja és elemezi azon mutatókat, amelyek számszerüsítik Kína előrehaladását az új fejlesztési pályára való áttérés során, kitérve a hagyományos mérési megközelítések hiányosságaira is. Az elemzés megállapítja, hogy számos, a nemzetközi összehasonlításban rendszeresen használt mutató valóban megerősíti a kínai modernizációs stratégiaváltás eredményeit, s alátámasztja azt az optimista forgatókönyvet, amely szerint Kína magas jövedelmű státusa a közeljövőben elérhetővé válik. Ugyanakkor szükséges néhány nehezen számszerüsíthető, általános és minőségi feltételekkel körülhatárolható tényezőt is figyelembe venni. Ez utóbbi tényezőcsoport szorosabb kapcsolatot mutat az egyes országok fejlettségi szintjével, valamint a közepes jövedelmü országok fejlődési lehetőségeivel. E sajátosságok tekintetében pedig Kínának még hosszú utat kell megtennie, hogy a magas jövedelmü kategóriába kerülhessen. ${ }^{*}$ Journal of Economic Literature (JEL) kód: F63, L16, O14, P20, Q55.
\end{abstract}

\section{Problémafelvetés és kutatási kérdések}

A 2010-es évek eleje óta a nemzetközi szervezetek közép- és hosszú távú előrejelzései a világ növekedési trendjének lassulását vetítik elöre (1. ábra). A növekedéslassulás magyarázó tényezőinek szerepéről erőteljes vita alakult ki a világ vezető közgazdászainak körében, akárcsak a további növekedési kilátásokról (Adler és szerzőtársai [2017], Baily és szerzőtársai [2013], Remes és szerzőtársai [2018]).

* A cikk a Pallas Athéné Innovációs és Geopolitikai Alapítvány által támogatott projekt keretében, továbbá a Bolyai János Kutatási Ösztöndíj támogatásával készült. A szerző továbbá szeretne köszönetet mondani Szalavetz Andrea, valamint a névtelen bírálók szöveggel kapcsolatos észrevételeiért és javaslataiért is.

Szunomár Ágnes tudományos munkatárs, kutatócsoport-vezető, KRTK Világgazdasági Intézet; egyetemi adjunktus, Budapesti Corvinus Egyetem.

A kézirat első változata 2019. augusztus 31-én érkezett szerkesztőségünkbe.

DOI: http://dx.doi.org/10.18414/KSZ.2019.12.1312 
1. ábra

OECD-prognózis - a reál-GDP alakulása (százalék)

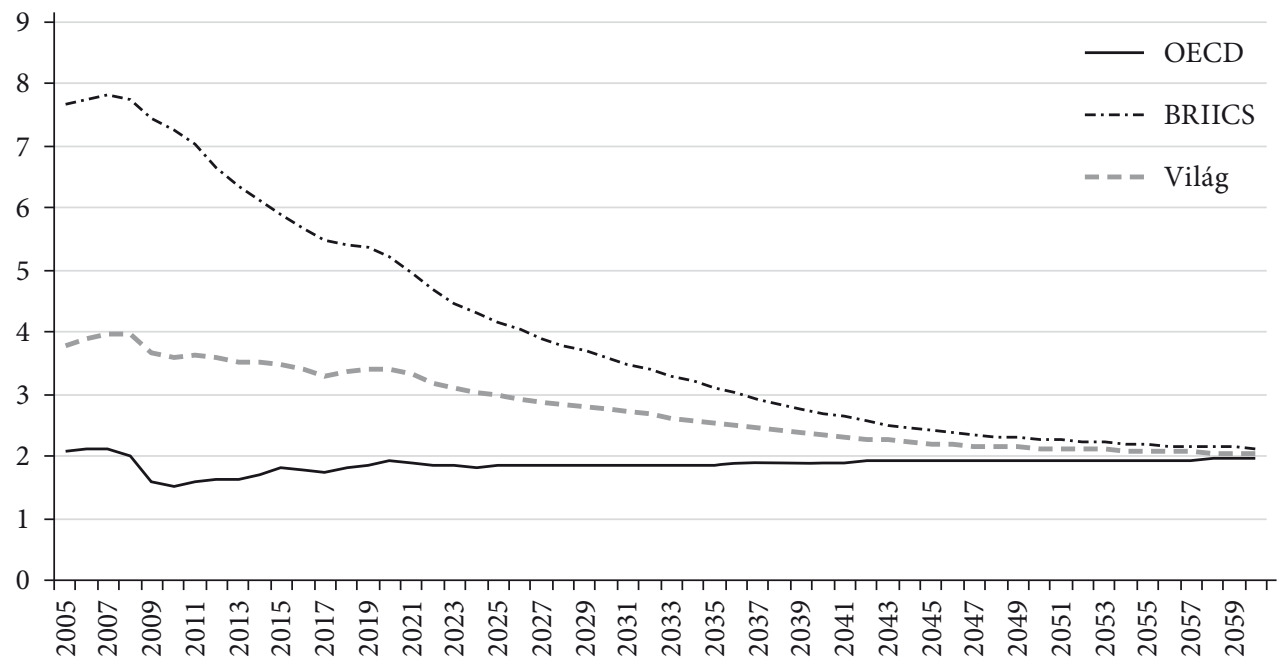

Megjegyzés: BRIICS-országok: Brazília, Oroszország, India, Indonézia, Kína, Dél-Afrika. Forrás: Guillemette-Turner [2018] adatai alapján saját szerkesztés.

Néhány közgazdász évszázados stagnálásról, a gazdasági növekedés és a termelékenységemelkedés erőteljes lassulásáról beszél (például Eo-Morley [2018], Gordon [2014]; lásd még Dufrénot-Rhouzlane [2018] és Syverson [2017] áttekintéseit). A növekedés lassulását részben gazdaságpolitikai hiányosságokra, a beruházások stagnálására, politikai bizonytalanságokra, a 2008-as globális válság elhúzódó hatásaira, mérési problémákra és demográfiai okokra vezetik vissza, részben a gazdasági szerkezet folytatódó átalakulásával, az alacsony termelékenységű (termelékenységemelkedésre képes) szolgáltatási szektorok GDP- és foglalkoztatási arányának növekedésével magyarázzák. Ugyanakkor az 1. ábrából egyértelmüen kitünik, hogy a globális növekedési teljesítmény eddigi és várható további kedvezőtlen alakulását elsősorban a BRIICS-országok (Brazília, Oroszország, India, Indonézia, Kína, Dél-Afrika) korábbiaknál mérsékeltebb növekedése magyarázza (Guillemette-Turner [2018]). Érdemes azonban megjegyeznünk, hogy a növekedés lassulása ellenére ennek az országcsoportnak és ezen belül leginkább Kínának és Indiának a világ GDP-jéhez való hozzájárulása folyamatosan nő: az OECD előrejelzése szerint Kína részesedése a 2030-as évek közepén a világ GDP-jének 27 százaléka lesz, ezt követően némileg csökken (2. ábra).

Kína évtizedeken keresztül produkált két számjegyü növekedést a kínai gazdasági csoda időszakában, amely az 1978. évi „reform és nyitás” politikájának meghirdetésétől tulajdonképpen 2008-ig, a globális gazdasági válság évéig tartott (3. ábra). A 2010-ben mért 10,4 százalékos növekedés 2016-ra 6,7 százalékra csökkent, ami 3 százalékos lassulási rátának felel meg (Tian [2019]). A csökkenés nem egyenletesen oszlott meg az egyes szektorok között: a primer szektor (mezőgazdaság, bányászat) növekedése 4,3 százalékról 3,3 százalékra, a szekunderé (ipar) 12,7 százalékról 
2. ábra

Kína részesedése a világ GDP-jéből (százalék)

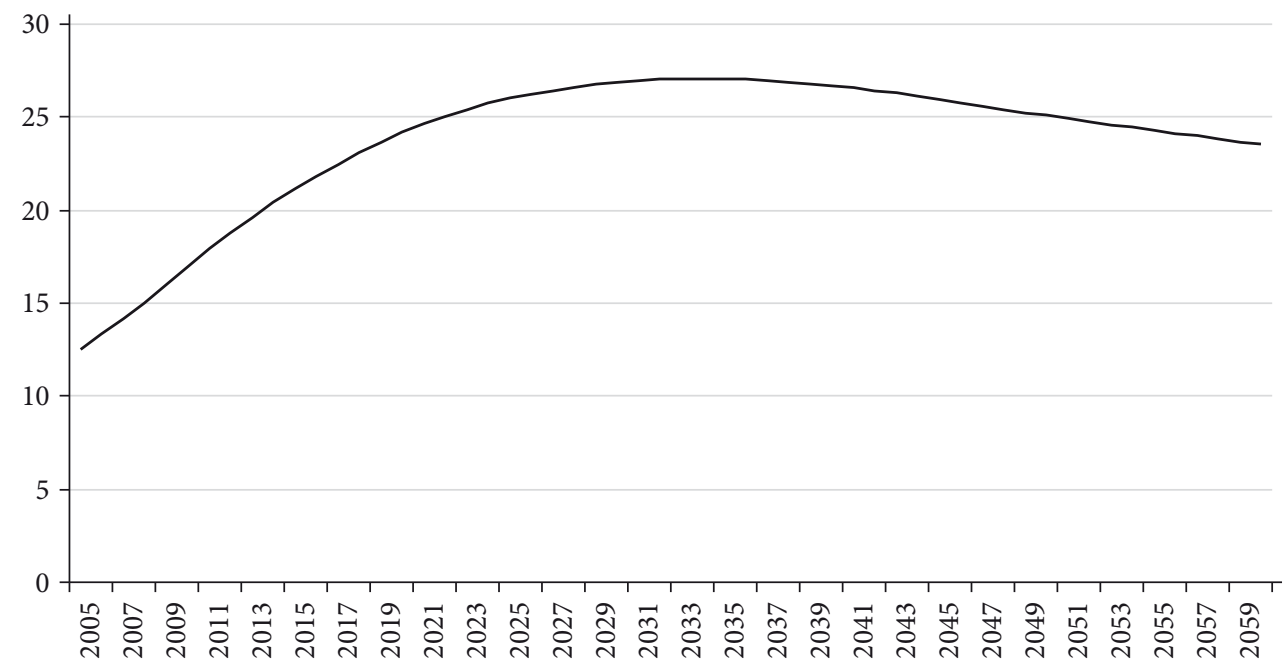

Forrás: Guillemette-Turner [2018] adatai alapján saját szerkesztés.

6,1 százalékra, a tercieré (szolgáltatás) pedig 9,7 százalékról 7,8 százalékra csökkent (Xu [2019]). A közgazdászok egyetértenek abban, hogy a növekedés elsődleges keresleti összetevői közül a beruházások visszaesése gyakorolta a legerősebb hatást, de a fogyasztás és az export növekedése is mérséklődött (például OECD [2019a], [2019b], Xu [2019]). Ma már a kínai kormányzat sem prognosztizál újabb két számjegyü növekményt: deklaráltan a hat-hat és fél százalék körüli növekedés válik az új normává, miközben a strukturális átalakulás ${ }^{1}$ az elmúlt bő másfél évtizedben folyamatosan formálja, modernizálja a kínai gazdaságot.

Az elmúlt években Kína jelentős erőfeszítéseket tett gazdasági szerkezetének korszerüsítésére, a növekedés új forrásainak megteremtésére, az emberi tőke felhalmozására és saját technológiafejlesztési képességeinek javítására. A digitalizáció a kínai gazdaság fejlesztésének kulcsterületévé vált. Folyamatosan bővül az a kínai és nemzetközi szakirodalom, amely dokumentálja és elemzi az új növekedési modell megalapozása érdekében tett erőfeszítéseket és azok következményeit. A kínai iparpolitika figyelemre méltó sikereit számos mutató igazolja, amelyek szerint Kína egyre inkább megközelíti az Egyesült Államok szintjét. A növekedés jelenlegi lelassulása

${ }^{1}$ Tanulmányunkban a „strukturális átalakulás” kifejezést hagyományos értelemben, az egyes gazdasági szektorok, iparágak GDP-részesedésének változása értelmében használjuk. E jelentés mellett a közgazdasági szakirodalomban és a nemzetközi szervezetek jelentéseiben gyakran elöfordul a „strukturális problémák” másfajta értelmezése (például OECD [2019b]). Eszerint a növekedést és a fejlődést olyan „strukturális problémák” akadályozzák, mint a kevéssé hatékonyan működő állami vállalatok, a jelentős tartományi szintü eladósodás, a piac kevéssé hatékony mủködése vagy a jelentős piacra lépési korlátok. Lin [2019] szerint ezek a strukturális problémák felelősek a növekedés utóbbi évtizedben bekövetkezett lassulásáért is. Tanulmányunkban ezeket nem strukturális, hanem intézményi hatékonytalanságnak tekintjük, és mivel ezek a kutatási témánkhoz csak távolról kapcsolódnak, nem foglalkozunk velük. 
3. ábra

A kínai GDP volumene és növekedésének üteme, 1978-2018

Ezer milliárd dollár

Százalék

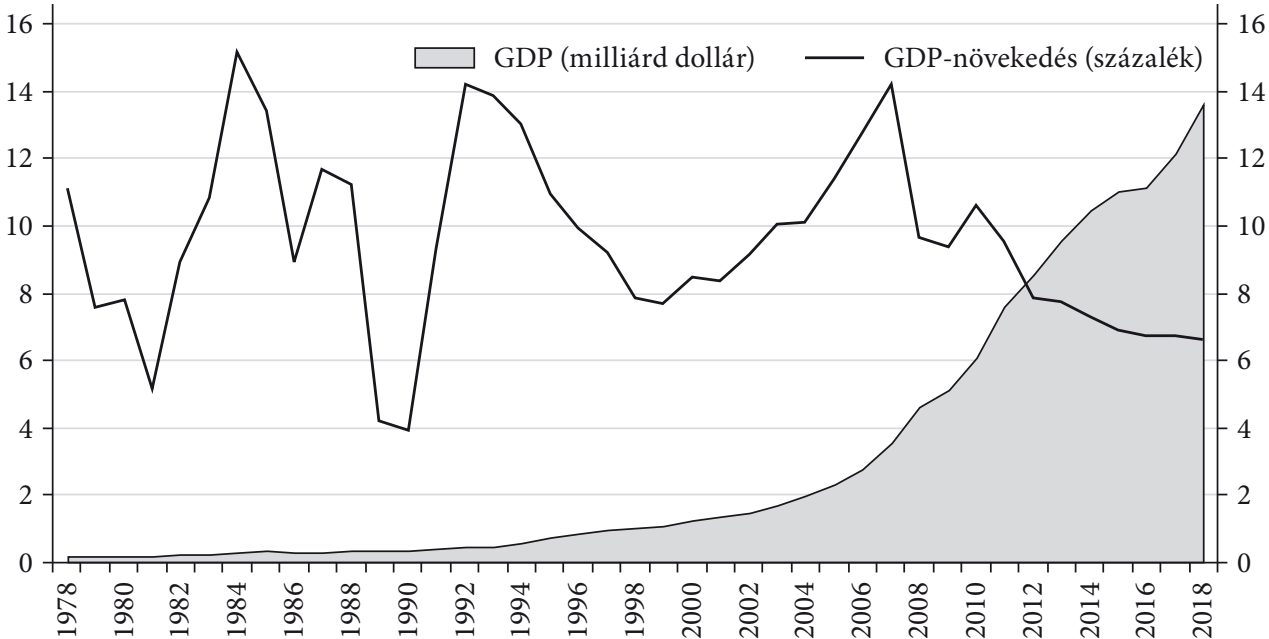

Forrás: Világbank.

ellenére e mutatók egy ambiciózus ütemterv rendkívül hatékony végrehajtására utalnak, ami végső soron hozzásegítheti Kínát a felzárkózáshoz, a magas jövedelmü státushoz és a globális technológiai vezető pozíció eléréséhez. Ezzel szemben néhány szakértő a mély szerkezeti hiányosságokra hívja fel a figyelmet, azt állítva, hogy ezek a mutatók - bármennyire is lenyügözőnek tűnnek - pusztán felszínes eredmények, és a felzárkózáshoz sokkal mélyebb változásokra van szükség.

Ha történetileg és összehasonlító módon elemezzük a feltörekvő országok fejlődését, azt láthatjuk, hogy a hatvanas, hetvenes, nyolcvanas években számos, elsősorban ázsiai és latin-amerikai fejlődő ország produkált látványos és gyors gazdasági növekedést, részben az exportösztönző és - ezt kiegészítendő - az egyes iparágak védelmét és/vagy elömozdítását támogató kormányzati intézkedéseknek köszönhetően. Ilyen természetü lépéseket tett, illetve bizonyos tekintetben tesz Kína ma is gazdasága fejlesztése érdekében. Az előbb említett, gyors fejlődést produkáló gazdaságok nagy része esetében azonban előbb-utóbb a növekedés kifulladt: stagnált, vagy a korábbiakhoz képest alacsonyabb szinten maradt, s az országok, ha be is kerültek a világbanki klasszifikáció szerinti közepes jövedelmü országok valamelyik csoportjába, meg is rekedtek ott. Csak néhány gazdaság - például Szingapúr, Tajvan, Dél-Korea, illetve Japán még jóval korábban - volt képes arra, hogy átlépjen a magas jövedelmü országok csoportjába.

Vajon Kína esetében az utóbbi években tapasztalt lassulás is a közepes jövedelmi csapda jelenségének bizonyítéka lenne? Kevéssé valószínű. Kína valójában nem a közepes jövedelmi csapda foglya: alig tíz éve van a felső-közepes jövedelmi sávban, de a Világbank Kínára vonatkozó éves egy főre jutó bruttó nemzetijövedelem-adataival kalkulálva, akár öt-tíz éven belül bekerülhet a magas jövedelmi kategóriába. 
A közepes jövedelmi csapda veszélye nem ismeretlen a kínai vezetés számára, gazdaságpolitikai beavatkozásainak egy részét pedig már több mint egy évtizede ennek elkerülése motiválja. Ennek jegyében keresi és erősíti a gazdasági növekedés új mozgatórugóit, és igyekszik a modernizációs stratégiaváltás feltételeit megteremteni a helyi innovációs képességek fejlesztésével, oktatási és $\mathrm{K}+\mathrm{F}$-beruházásokkal, a feltörekvő iparágak és technológiák szisztematikus fejlesztésével és különösen a digitális átalakulás erőltetett ütemű felgyorsításával.

Hipotézisünk szerint a kínai növekedés lassulása nem a közepes jövedelmi csapda jele, hanem részben a csapda elkerülése érdekében elindított modernizációs stratégiaváltás kísérőjelenségének tekinthető, hiszen strukturális átalakulások során óhatatlanul lassul a növekedés üteme. Tanulmányunkban egyrészt sorra vesszük azokat a tényezőket, mutatókat, amelyek alátámasztják hipotézisünket, azaz bizonyítják azt, hogy Kína növekedési lassulása nem a közepes jövedelmi csapda következménye vagy annak elöszobája, hanem a modernizációs stratégiaváltás kísérőjelensége, másrészt azt vizsgáljuk meg, hogy alkalmas-e a feltörekvő technológiák szisztematikus fejlesztése és a digitális átalakulás erőltetése a kínai gazdasági növekedés felgyorsítására és a kívánt modernizációs stratégiaváltás megvalósítására.

A közepes jövedelmi csapdáról szóló szakirodalom rövid áttekintését követően megvizsgálunk néhány olyan mutatót, amelyek a közepes jövedelmi csapda tematikájú szakirodalomban szerepelnek, majd azt elemezzük, hogy Kína ezek alapján besorolható-e az e csapdában megrekedt országok csoportjába. Olyan mutatókat is nagyító alá helyezünk, amelyek a modernizációs stratégiaváltást jellemzik. $\mathrm{Az}$ alapvető strukturális mutatók mellett ezek az ipari és technológiai szakosodás, az export finomra hangolása, a technológiai függőség csökkentése, az emberitőkefelhalmozás, az innováció és a digitalizáció, továbbá a hazai tulajdonú innovatív vállalatok nemzetközi sikerei. A modernizációs stratégiaváltás digitalizációval összefüggő szempontjait külön fejezetekben elemezzük, ennek keretében bemutatjuk többek között a kínai mesterséges intelligencia (MI) stratégiát és a „Made in China 2025” programot, illetve a kínai vállalatok szerepét a digitális átalakulás során. A tanulmányt következtetésekkel zárjuk.

\section{A közepes jövedelmi csapda}

A közepes jövedelmi csapda fogalmát először - latin-amerikai és közel-keleti példákra való hivatkozással - a Világbank két vezető közgazdásza, Indermit Gill és Homi Kharas említette a kelet-ázsiai országok gazdasági reneszánsza kapcsán (Gill-Kharas [2007]). A későbbi publikációkkal (Yusuf-Nabeshima [2009], Ohno [2009]) összhangban már ők is kiemelték, hogy a közepes jövedelmű sávba tartozó országok számára a növekedés fenntartása komoly kihívásokat jelenthet, amelyeket csak megfelelő gazdaságpolitikai és intézményi reformokkal lehet leküzdeni, ahol többek között az innováció, az új technológiák és az oktatás játszhatnak fontos szerepet a csapda elkerülésében. Azóta több szerző - gyakran egymástól eltérő módszerekkel, számításokkal - tett kísérletet arra, hogy megmagyarázza, miért rekednek meg egyes országok a közepes jövedelmü 
szinten, s miért nem képesek előrelépni a magas jövedelmű csoportba (Eichengreen és szerzötársai [2013], Kharas-Kohli [2011], Felipe és szerzőtársai [2012], Didier és szerzőtársai [2016], Jayasooriya [2017]). A kifejezés tehát általában olyan országokra utal, amelyek huzamosabb időn keresztül gyors növekedést produkáltak, és ezáltal relatíve rövid idő alatt váltak alacsony jövedelmü országból közepes jövedelművé, e kategórián belül pedig viszonylag gyorsan kerültek az alsó-közepes sávból a felsőbe, ugyanakkor a további felzárkózás - a magas jövedelmüek csoportjába - már nem volt sikeres, s az országok megrekedtek a közepes fejlettségi szinten.

A fenti tárgyalás ugyanakkor nem feltétlenül szakszerü meghatározása a közepes jövedelmü országok csapdajelenségének, ugyanis annak ellenére, hogy e téma viszonylag régóta foglalkoztatja a közgazdaság-tudományt, a kifejezésnek nincs egyértelmủ és elfogadott definíciója. A legtöbb ezzel foglalkozó tanulmány ugyanis nem alkot pontos meghatározást, sokkal inkább e csapdahelyzet lehetséges jellemzőit ismerteti. A Nemzetközi Valutaalap közgazdászai például öt tényezőcsoportot említenek a közepes jövedelmi csapda lehetséges attribútumaiként: 1 . az intézmények minősége, 2. demográfiai jellemzők (a társadalom elöregedése, a munkaképes korú lakosság száma, szektorok szerinti eloszlása stb.), 3. infrastruktúra, 4. makrogazdasági környezet és politika (ideértve többek között a külkereskedelmi nyitottságot, a beruházási hányadot, a tőkebeáramlás és az államadósság mértékét) és 5. a gazdaság szerkezete (Aiyar és szerzőtársai [2013]). Az Ázsiai Fejlesztési Bank közgazdászai is kiemelik a kereskedelem, azon belül is a diverzifikált és minőségi értelemben finomra hangolt export szerepét, akárcsak a strukturális átalakulásét (Felipe és szerzőtársai [2012]). Más szerzők a demográfiai és makrogazdasági változókon túl kiemelik még az emberi tőke és az oktatás, valamint az innováció és az új technológiák szerepét is (például Eichengreen és szerzőtársai [2013], Jayasooriya [2017], Glave-Wagner [2017]).

Kína gazdasága jelenleg egyértelmüen a közepes jövedelmü kategóriába - annak is leginkább a felső sávjába - tartozik. A Világbank terminológiája szerint ${ }^{2}$ Kína 1999-ben vált alacsony jövedelműből közepes jövedelmủ országgá, ekkor még csak az alsó jövedelmủ sávba (lower-middle income) lépve be, míg 2010 óta a közepes jövedelmü országok felső sávjába (upper-middle income) tartozik. Ennek megfelelỏen a következő lépcsőfokok egyike valóban a közepes jövedelmủ szintröl a magas jövedelmű kategóriába történő átmenet, mely kihívás a kínai vezetők különböző nyilatkozataiban is megjelenik az utóbbi években.

Az Ázsiai Fejlesztési Bank közgazdászai 124 ország növekedését vizsgálták a Maddison adatbázis alapján, amelyet a World Economic Outlook (WEO) 2011-es növekedési

\footnotetext{
${ }^{2}$ A Világbank klasszifikációja szerint beszélhetünk alacsony jövedelmü (low income, LI), közepes jövedelmü - ezen belül megkülönböztetve alsó (lower-middle income, LMI) és felső (upper-middle income, UMI) kategóriákat -, illetve magas jövedelmű (high income, HI) országok csoportjáról. $\mathrm{Az}$ évente frissített klasszifikáció jelenlegi küszöbértékei alapján alacsony jövedelmű kategóriába tartozik egy ország, ha az egy före jutó bruttó nemzeti jövedelem (Gross National Income, a továbbiakban GNI/fö) 1005 dollár alatt van; közepes jövedelmü csoportba sorolódnak azon országok, ahol a GNI/fö 1006 és 12235 dollár között mozog (ezen belül LMI, ha a GNI/fő 1006 és 3955 dollár közötti, és UMI, ha 3956 és 12235 dollár közötti); míg magas jövedelmű kategóriába kerül minden ország, ahol a GNI/fö 12236 dollár fölött van.
} 
adataival egészítettek ki (Felipe és szerzőtársai [2012]). Számításaik szerint egy országról akkor állítható, hogy közepes jövedelmi csapdában van, ha az alsó-közepes jövedelmi tartományban (LMI) több mint 28 éve vagy a felső-középső jövedelem tartományában (UMI) több mint 14 éve tartózkodik. Megállapításaik szerint Kína 17 év alatt volt képes fellépni az alsó-közepes jövedelmü sávból a felsőbe, ami jóval rövidebb, mint az általuk kiszámolt 28 éves periódus. Felipe és szerzőtársai szerint tehát Kína már 2009 óta a felsőközepes jövedelmủ sávban van, és jó eséllyel még a kritikus 14 év lejárta - tehát 2023 előtt képes lesz feljutni a magas jövedelmü országok csoportjába.

Glawe-Wagner [2017] ezt a számítási módszert vitte tovább, és arra jutott, hogy Kína tulajdonképpen már 2016-ban, azaz hét - a felső-közepes jövedelmű csoportban eltöltött - év elteltével feljutott a magas jövedelmü tartományba, legalábbis Felipe és szerzőtársainak módszere szerint. Kína és a közepes jövedelmi csapda kapcsán Glawe-Wagner [2019] számos, többek között a fentiekben is említett szerzök megközelítési módszereit és számításait vetette össze, az emberi tőke, az exportszerkezet és a teljes tényezőtermelékenység tényezőire helyezve a hangsúlyt. A szerzőpáros megállapításai szerint Kína ugyan tartósan a közepes jövedelmi sávban helyezkedik el, de a közepes jövedelmi csapdába való bekerülése kevéssé valószínű. Ezt a helyzetet csak a növekedés egy jelentősebb lassulása idézhetné elő, amennyiben a kínai gazdaság tartósan csupán 3-4 százalékos növekedésre lenne képes.

\section{A kínai strukturális átalakulás sajátosságai - a növekedés motorjai, demográfia, oktatás és innováció}

A fejlődés-gazdaságtan főbb képviselői szerint a fejlődés és a növekedés a termelési szerkezet strukturális átalakulásának folyamata (például Lewis [1955], Rostow [1959], Kuznets [1966], Kaldor [1967], valamint Chenery-Taylor [1968]). Ez magában foglalja az eröforrások - a munka és a töke - átcsoportosítását az alacsonyabb termelékenységű tevékenységekből a magasabb termelékenységüekbe, vagyis jellemzően a mezőgazdaságból az ipar és szolgáltatások területére. Kuznets [1971] szerint a fejlődés az előbbieken túl a tőkefelhalmozást, az iparosítást és új termékek új termelési módszerekkel történő gyártását, az urbanizációt és a társadalmi intézményekben és hiedelmekben bekövetkezett változásokat is jelenti.

A fentieket továbbgondolva megállapítható, hogy a maga módján Kína is fejlődésének elörehaladott szakaszában van, hiszen a szekunder és tercier szektor túlsúlya jellemző (4. ábra). E szektorok GDP-hez viszonyított aránya pedig jól tükrözi az ország fejlődésének előrehaladottsági fokát is: a mezőgazdaság GDP-arányos részesedése - bár jelentősebb, mint a fejlett világ országaiban - 10 százalék alatti csupán, míg a szolgáltatások már a GDP több mint 50 százalékát adják.

A strukturális átalakulással kapcsolatban azonban ki kell emelnünk, hogy a mezőgazdaságban foglalkoztatottak aránya a Nemzetközi Munkaügyi Szervezet (ILO) adatai alapján Kínában még mindig igen jelentős, a teljes munkaerőnek legalább 27 százaléka, azaz az említett erőforrás-átcsoportosítás e téren még korántsem ment végbe teljesen. 


\section{4. ábra}

A kínai gazdaság szektorainak aránya a GDP-ben, 2018 (százalék)

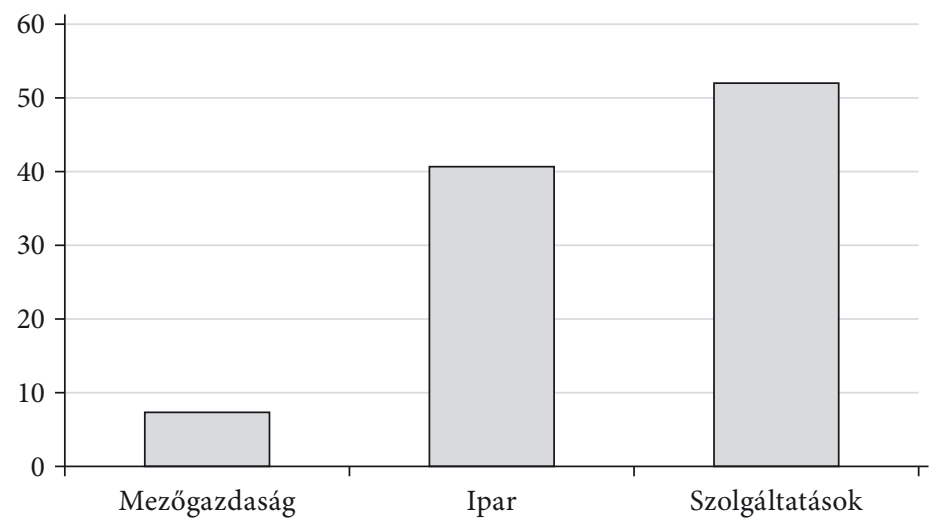

Forrás: Világbank.

A nagy növekedési hullámot, a „kínai gazdasági csodát” a strukturális átalakulás táplálta, az említett termelési tényezők és beruházások újraelosztása, azaz a munkaerő átirányítása az alacsony termelékenységű szektorokból a magas termelékenységüekbe vagy éppen az állami tulajdonú vállalatokból a magántulajdonúakba. Sőt strukturális átalakulás révén kívánják kezelni a kínai gazdaság jelenlegi problémáit is: a kínai kormányzat tervei szerint az eleinte exportvezérelt, az utóbbi évtizedben pedig már sokkal inkább beruházásvezérelt növekedést a belső fogyasztásra és - a szekunder helyett - még inkább a tercier szektorra alapozó növekedésnek kell felváltania.

Ahogy az az 5. ábrán is látható, a fogyasztás szerepe egyre jelentősebb a kínai GDPben, míg az export/GDP adat - kisebb visszapattanásoktól eltekintve - már 2006 óta folyamatosan csökken. Ami a bruttó megtakarítás/GDP mutatót illeti (amely Kína esetében a világátlag közel kétszerese), Kínának nincs oka szégyenkezésre, annak ellenére, hogy a komolyabb gazdasági lassulás elkerülése érdekében a 2008-as gazdasági és pénzügyi válság utáni években tartalékainak egy részét felhasználta.

Aiyar és szerzőtársai [2013] a tartós növekedéssel kapcsolatban - az eddig említett tényezőkön túl - a tőkebeáramlás és az államadósság mértékének szerepét is kiemeli. A szerzők szerint a növekedés lelassulásának valószínüsége jelentősen megnő, ha a bruttó tőkebeáramlás kezdeti szintje rendkívül nagy, vagy az államadósság szintje magas (ez utóbbi esetben alacsonyabb mértékben). Az utóbbi években Kína tőkebeáramlás/GDP mutatója 1,5 százalék körül mozog, ami összességében alacsonynak számít, ráadásul folyamatosan csökken (1993-ban még 6 százalék felett volt), így e mutató kapcsán - Aiyar és szerzőtársai számításait alapul véve a kínai növekedés lassulásának valószínüsége csekély. Az államadósság a Nemzetközi Valutaalap statisztikái szerint Kínában a GDP 46 százaléka, ami ugyan nem kiugró, de relatíve magasnak is tekinthető. Meg kell jegyeznünk ugyanakkor, hogy az ország teljes adóssága már a GDP 270 százaléka körül mozog, ami a kínai növekedés jövőjének egyik legkritikusabb kérdése. 
5. ábra

A kínai megtakarítás, beruházás, fogyasztás és export a GDP százalékában, 2017

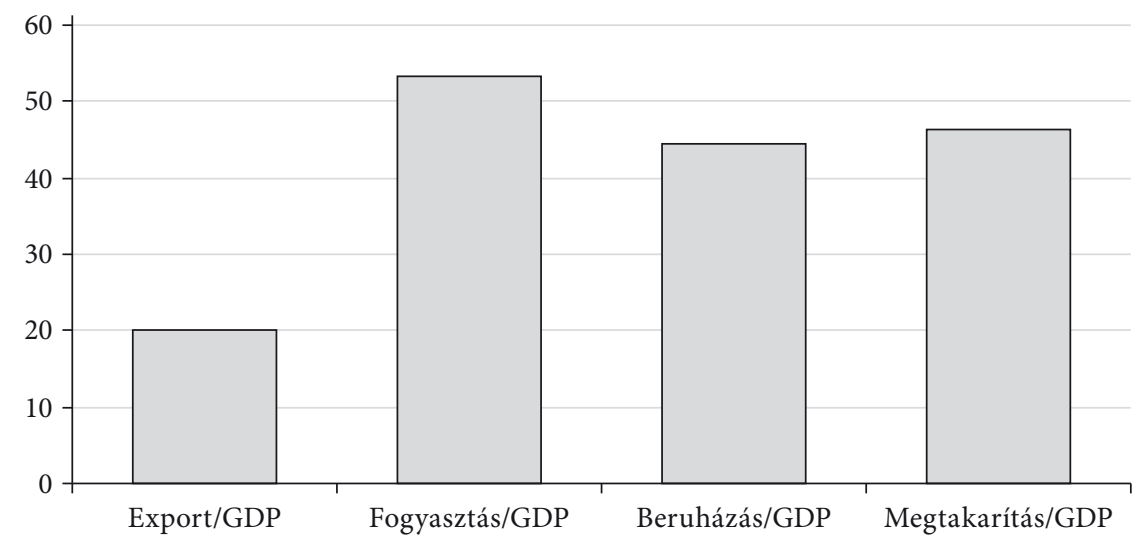

Forrás: Világbank.

A strukturális átalakulás kapcsán érdemes kitérni az ország demográfiai kihívásaira is (6. ábra). Kína a világ legnépesebb országa, lakóinak száma 1,38 milliárd fö, ami azonban nem jelenti azt, hogy ne kellene szembesülnie olyan komoly demográfiai problémákkal, mint a népességcsökkenés, illetve annak közelgő veszélye. Kínában az elmúlt években már csupán fél százalék körüli népességbővülés a jellemző, lakóinak száma 2030 körül fog tetőzni - 1,45 milliárdon -, majd fokozatosan kezd csökkenni. Igaz, az utóbbi időben tapasztalható némi elmozdulás pozitív irányba, köszönhetően a kínai kormányzat új, „egy család-két gyermek” politikájának.

6. ábra

Kína népessége és népességének növekedési üteme, 1978-2018

Millárd fö

Százalék

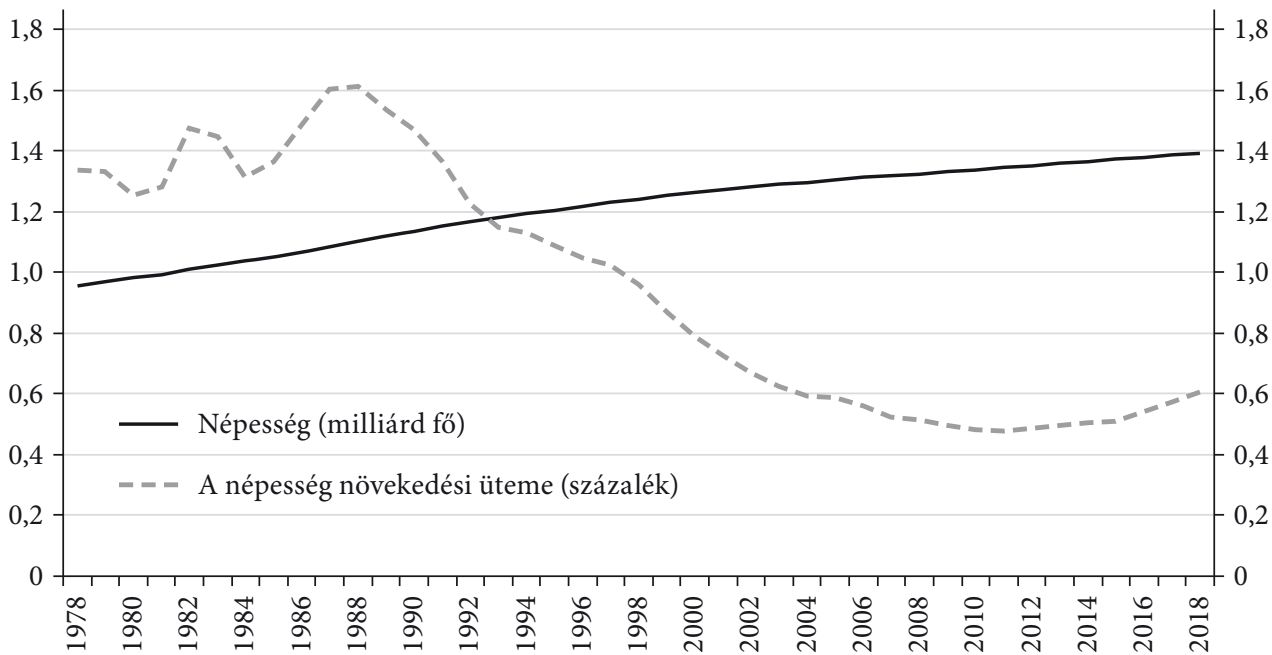

Forrás: Világbank. 
A fejlődés hajtóerejét boncolgató szakirodalom alapján azonban nem is a népesség növekedésének üteme, sokkal inkább a népesség kor szerinti eloszlása a meghatározó, Kelet-Ázsiában különösképp (lásd például Bloom és szerzötársai [2000], Mason [2001], Aiyar és szerzötársai [2013]). Ebben a régióban ugyanis a gyors növekedés, a „gazdasági csoda" hátterét minden esetben a fiatal, növekvő számú munkaerő adta, e korszak azonban Kína számára is a végéhez közeledik: várhatóan 2050 után áll elő az az állapot, hogy a társadalom negyedét a 65 év felettiek adják majd. Kínában ma 100 aktív korúra nagyjából 14 időskorú (időskori függőségi ráta) és 24 fiatalkorú (fiatalkori függőségi ráta) jut, miközben a munkaerőpiac szempontjából releváns 15-64 évesek létszáma 2010 óta csökkenést mutat, jelenleg a teljes populáció 72,2 százaléka aktív korú.

A Nemzetközi Valutaalap becslései alapján az elkövetkező három évtizedben a munkaképes korúak száma Kelet-Ázsiában több százmillióval csökkenhet, Kína esetében ez megközelítőleg 170 millióval kevesebb munkavállalót jelent (Amaglobeli-Shi [2016]), ami jó eséllyel már a termelékenység növekedési ütemét is befolyásolhatja. A probléma megoldásában a munkaerőpiaci reformok kulcsfontosságúak, Japán és Dél-Korea például a női foglalkoztatottság növelésével - a gyermekgondozási intézmények bővítésével és a rugalmas foglalkoztatás előmozdításával párhuzamosan - próbálja orvosolni azt, hogy ezen országokban nagyon alacsony a női munkaerő részvételi aránya (50, illetve 52 százalék). Kínában ez az arányszám ugyan folyamatosan csökkenő, de még így is magasabb: 61 százalék. Ez a szint jóval a fejlett országok mutatói felett van.

A kínai munkaerőpiaci részvétel csökkenése kapcsán meg kell jegyeznünk, hogy az nem kizárólag a népességcsökkenés eredménye, hanem befolyásolhatja például a felsőoktatás 1990-es években kezdődő gyors bővülése, a nők munkaerőpiacról való korábbi visszavonulása, illetve a minden korcsoportban megfigyelhető munkaerőpiaci részvétel általános csökkenése is. A felsőoktatás bővülésével például a fiatal felnőttek ugyan később, de jobb képesítéssel, nagyobb tudással lépnek be a munkaerőpiacra és járulnak hozzá a jövőbeli termelékenységnövekedéshez és a magasabb bérekhez. Továbbá e folyamat a munkaerö mobilitását is növelheti, ami pedig már a gazdasági hatékonyság növelésének lehetőségét is magában hordozza. Kína esetében az aktív korúak egy részének munkaerőpiaci inaktivitása - például a nők esetében - egyértelműen az utóbbi tíz-tizenöt év terméke, amit a gazdasági jólét adott szintjének elérése tett lehetővé a kínai családok számára.

A kínai munkaerő mennyisége tehát távlatilag ugyan folyamatosan csökkenni fog, termelékenysége viszont mindeközben gyors ütemben növekszik, hiszen az emberi tőke kínai felhalmozódása a fejlett gazdaságokéhoz közelít, nem is beszélve a Kínában is terjedö - és az állam által is ösztönzött - robotizáció pozitív hatásairól. Kína e tekintetben igen előrelátó volt, és időben - de fokozatosan - kezdte meg az átállást az alacsony költségű munkaerőre alapozó stratégiáról előbb az imitációra, majd az innovációra alapozó stratégiára.

Ami az emberi tőke felhalmozódását illeti, Eichengreen és szerzőtársai [2013] vizsgálatai azt mutatták ki, hogy a növekedés lassulása ritkábban fordul elő olyan országokban, ahol a népesség nagy része legalább középfokú végzettséggel rendelkezik. Hangsúlyozzák továbbá a „magas színvonalú emberi tőke” szerepét (szemben a „gyenge színvonalúval”), amely - a képzett munkaerő révén - nélkülözhetetlen 
a magas hozzáadott értéket képviselő tevékenységekhez és a strukturális átalakítás sikeres menedzseléséhez is (lásd még Tho [2013] 110. o.).

Az oktatásra fordított kormányzati kiadások tekintetében Kína sokat lépett elöre a 21 . század kezdete óta: míg 1999-ben a GDP kevesebb mint 2 százalékát költötték oktatásra, addig 2016-ban már 5 (kínai források szerint 4) százalékát. Összehasonlításképp: az OECD statisztikái szerint Japán ma GDP-jének 3,6, míg Dél-Korea 5,05 százalékát fordítja oktatásra, de az Eurostat 2017-re vonatkozó adatai alapján a kínai adat az uniós átlagot (4,6 százalék) is meghaladja. Ami az oktatásban történő részvételt illeti, a fejlődés itt is számottevő: Kína 2010 és 2015 között is jelentős eredményeket ért el (1. táblázat).

\section{1. táblázat}

Kínai beiratkozási arányok (a teljes népesség százalékában)

\begin{tabular}{lcccc}
\hline & Év & Általános iskola & Középfokú oktatás & Felsőfokú oktatás \\
\hline Kínai adat & 2010 & 100 & 83,00 & 23,00 \\
OECD-adat & 2015 & 100 & $94,29^{a}$ & 43,39 \\
\hline
\end{tabular}

${ }^{a}$ A középfokú oktatás kettéválik Kínában: a hatéves általános iskolai képzést követően a három vagy négy éven át tartó junior középiskolai képzés még kötelező, míg a hároméves szenior középiskola már nem az. Ennek ellenére a diákok közel 95 százaléka dönt úgy, hogy folytatja tanulmányait a tankötelezettség felső korhatárának elérését követően. 2005ben ez az arány még alig 40 százalékos volt.

Forrás: Barro-Lee Educational Attainment Dataset (2010) és az OECD 2015-ös adata.

A kínai statisztikai hivatal adatai szerint 2017-ben nyolcmillióan diplomáztak kínai egyetemeken, közel tízszer annyian, mint 1997-ben, és közel kétszer annyian, mint tavaly az Egyesült Államokban. A friss diplomásokat pedig szinte azonnal fel is szívja a munkaerőpiac: több mint 90 százalékuk hat hónapon belül elhelyezkedik.

E jelentős növekedés mögött több tényező együttes jelenléte sejthető: a növekvő középosztály igényei, a gazdasági növekedés által támasztott követelmények éppúgy ebbe az irányba hatottak, mint az explicit módon a felsőoktatás szélesítését célzó kormányzati politika. Ettől függetlenül, a középfokú és felsőoktatásban végzettek aránya Kínában ma is elmarad a fejlett országok adataitól. Ennek egyik lehetséges magyarázata a mezőgazdaságban foglalkoztatottak korábban már említett, viszonylagosan magas aránya (27 százalék), ebben a szektorban ugyanis valószínüleg kevésbé van igény a (közép- és) felsőfokú szakképesítésre. Távlatilag azonban az agrárszektorban dolgozók aránya csökkenni fog, ezzel párhuzamosan pedig várhatóan a közép- és felsőoktatásban végzettek aránya is tovább fog emelkedni.

Az oktatás során elsajátított készségek minőségét a PISA-felmérések ${ }^{3}$ eredményei segítségével mérhetjük. Tekintettel arra, hogy a PISA-eredmények esetében nem áll rendel-

${ }^{3}$ Az OECD PISA programja (Programme for International Student Assessment) a 15 éves diákok teljesítményének felmérése: a részt vevő országokban háromévente vizsgálják a diákok felkészültségét többek között a „való életre”, a munkaerőpiaci változásokra. A felmérés során minden országban kiválasztásra kerül egy olyan 4500-10 000 fős minta, amely a részt vevő országokban a 15 éves diákok teljes csoportját hivatott képviselni. 
kezésre korábbi adat (elöször 2000-ben készült ilyen felmérés, Kína pedig kezdetben nem is volt résztvevője), így a legutóbbi felmérés adatait vesszük alapul. Eszerint Kína minden tekintetben az OECD-átlag felett teljesít (lásd 2. táblázat). Hangsúlyozni szükséges ugyanakkor, hogy a PISA-eredmények jó eséllyel a valódinál pozitívabb képet festenek a kínai oktatás minőségéről. Mint minden, a PISA-felméréseken részt vevő országban, úgy itt is igaz, hogy a felmérésben részt vevő diákok nem feltétlenül reprezentálják az egész országot. Kínára ez már csak azért is különösen igaz, mert - az OECD engedélyével - a mintát a teljes ország helyett csupán néhány régióból választják ki. ${ }^{4}$

\section{2. táblázat}

Kína PISA-eredményei, 2015

\begin{tabular}{lccc}
\hline & Természettudomány & Szövegértés & Matematika \\
\hline OECD-átlag & 493 & 493 & 490 \\
Kína & 518 & 494 & 531 \\
\hline
\end{tabular}

Megjegyzés: a tanulmány véglegesítésének idején a 2018-as PISA-felmérés eredményeit még nem hozták nyilvánosságra.

Forrás: OECD.

A fent említett tényezőkön túl az innováció szerepe is nélkülözhetetlen a további növekedés szempontjából a fejlődő országok számára (Eichengreen és szerzötársai [2013], Jayasooriya [2017], Glave-Wagner [2017], [2019]). Zhuang és szerzötársai [2012] is arra a következtetésre jutott, hogy az innováció révén folyamatos ipari fejlesztésre van szükség, ily módon biztosítva az elmozdulást az alacsony költségűből a magas hozzáadott értékű gazdaság felé, amelyhez a kedvező makrogazdasági és piaci környezet mellett az erős (kormányzati) innovációs ösztönzők is nélkülözhetetlenek.

A technológiai fejlődést, innovációt a teljes tényezőtermelékenység (total factor productivity, TFP) is tükrözi, ${ }^{5}$ mindemellett a növekedési potenciál egyik további fontos mutatója is (7. ábra). Az Eichengreen és szerzőtársai [2013] által vizsgált országok növekedésében bekövetkezett lassulás mintegy 85 százalékát például a teljes tényezőtermelékenység növekedési ütemének csökkenése magyarázta, míg ugyanitt a munkaerő és a tőke csökkenése csak viszonylag kis szerepet játszott. Bulman és szerzötársai [2014] és Jitsuchon [2012] is arra a következtetésre jutott, hogy azokban az országokban, amelyekben sikeresen elkerülték a közepes jövedelmi csapdát, a teljes tényezőtermelékenység viszonylag magas növekedést mutatott, azaz az inputvezérelt növekedés helyett a teljes tényezőtermelékenység által vezérelt növekedés lehet a gazdasági növekedés egyik kulcsa a fejlődő országokban (Tho [2013]).

\footnotetext{
${ }^{4}$ A legutóbbi, 2015-ös felmérés során Kína esetében a tartományi szintű főváros, Peking, az ugyancsak tartományi szintű Sanghaj, az ország keleti partján elhelyezkedő Csiangszu és a déli partvidéken található Kuangtung tartományból származott a minta. A korábbi, 2009-es és 2012-es felmérések alkalmával egyedül Sanghaj vett részt a felmérésben, tehát a kínai minta ugyan a legutóbbi felmérés esetében sem feltétlenül reprezentatív Kína egészére nézve, de mindenképp szélesebb, mint a megelöző felmérések idején volt.

${ }^{5}$ A teljes tényezőtermelékenység a termelési folyamat összes ráfordításának hatékonyságát méri, növekedése mögött általában technológiai innováció vagy fejlesztés áll.
} 
7. ábra

A TFP növekedése néhány országban (nemzeti valutában, 2011-es állandó áron)

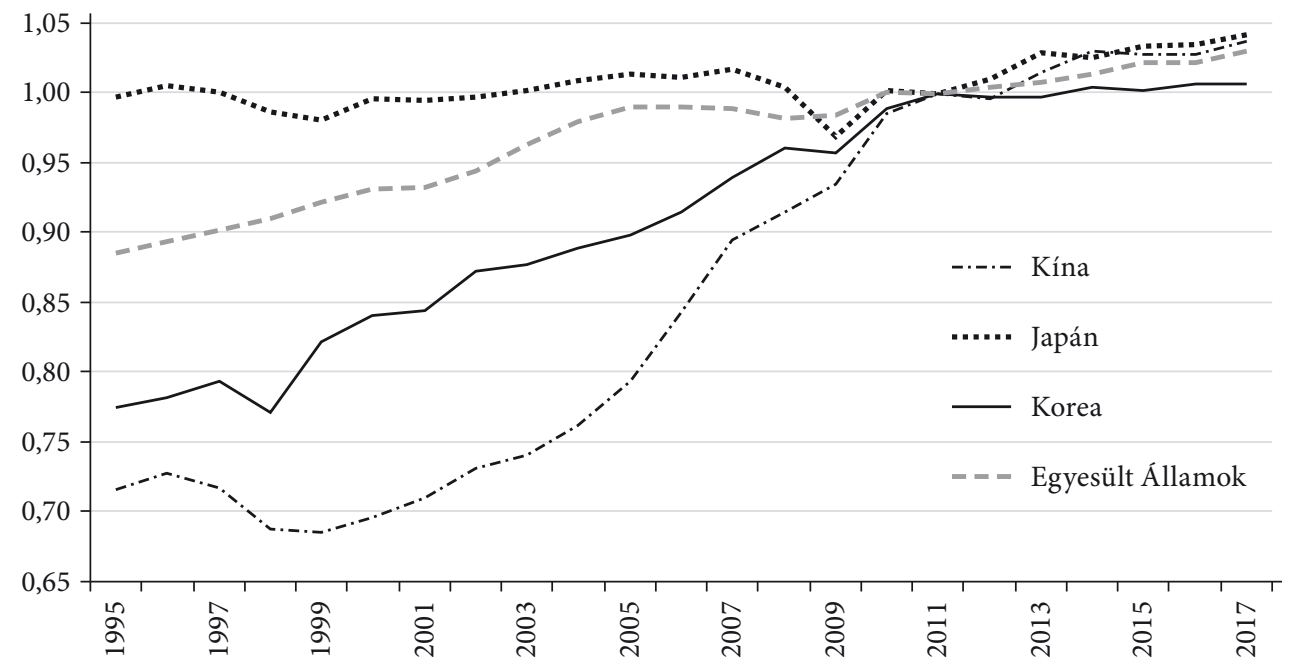

Forrás: Feenstra és szerzőtársai [2015] és a University of Groningen, Penn World Table adatai alapján saját szerkesztés.

A Groningen Egyetem által kiszámolt - és 2017-ig gyüjtött - TFP-adatok mindenesetre igazolják a fenti következtetéseket, hiszen a kínai teljes tényezőtermelékenység - akárcsak a gazdaság - valóban töretlenül növekszik az utóbbi évtizedekben (7. ábra), sőt a mutató növekedési üteme 2010-ig meghaladta a versenytársakét. 2010 után a teljes tényezőtermelékenység növekedési üteme mindegyik országban erősen lassul. Ami azonban a mutató szintjét illeti, a 8. ábrából kitünik, hogy az önmagához képest gyors növekedés ellenére a felzárkózás nem indult meg: Kína továbbra is erősen lemaradt mind az Egyesült Államokhoz, mind az ázsiai versenytársakhoz képest, noha ez utóbbiak felzárkózására sem került sor. ${ }^{6}$

Lin [2019] ugyanakkor az elmaradottságból fakadó előnyöket hangsúlyozza: a termelékenységi szakadéknak köszönhetően továbbra is jelentős a kínai gazdasági növekedési és termelékenységemelkedési potenciál. Kína egyelőre még nincs a technológiai élvonal közelében, így a termelékenység emelkedését nem csupán a meglehetősen kockázatos innovációs erőfeszítések táplálják. A korábban említett emberitőke-felhalmozás, a robotizáció és a másutt kifejlesztett technológia adaptálása még „az élvonalat kijjebb toló" önálló innovációk híján is jelentős hatást gyakorol a közeljövőben a kínai termelékenység növekedésére - állítja Lin. Ebből következően a modernizációs stratégiaváltásnak a következőkben részletesen tárgyalt célzott technológiapolitikai és iparpolitikai összetevője kulcsfontosságú szerepet játszik.

\footnotetext{
${ }^{6}$ Megjegyzendő ugyanakkor, hogy a Groningen Egyetem által összeállított TFP-adatbázis az optimistábbak közül való, főként Kínára nézve, így ez az eredmény inkább csak feltételezés, mint egyértelmü következtetés.
} 
8. ábra

A teljes tényezőtermelékenység szintje (Egyesült Államok =1)

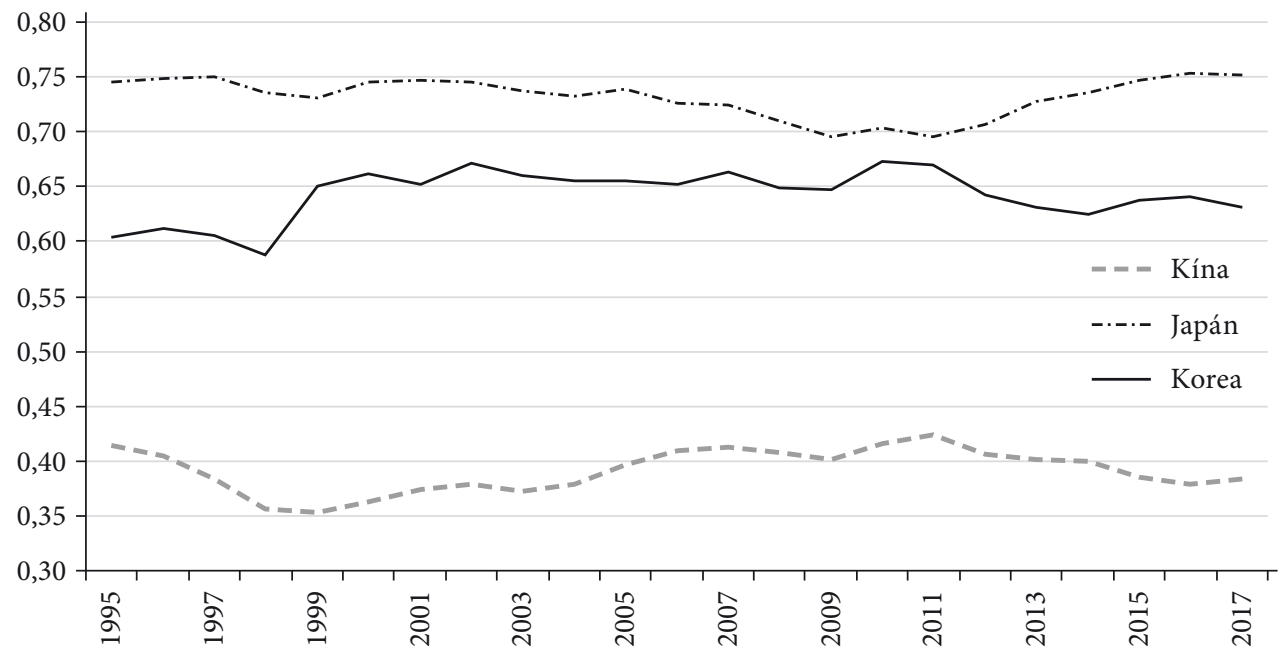

Forrás: Feenstra és szerzőtársai [2015], University of Groningen, Penn World Table adatai alapján saját szerkesztés.

A teljes tényezőtermelékenység növekedését erősen befolyásoló $\mathrm{K}+\mathrm{F}$-ráfordítások is a gazdasági fejlődés eredőit tárgyaló szakirodalom visszatérö és meghatározó elemei: hol a TFP kapcsán, hol attól függetlenül említik. A Világbank adatainak felhasználásával készített 9. ábra a K+F-ráfordításokat mutatja a GDP százalékában: a fejlődés az elmúlt két évtizedben szembetűnő. Kína eredményei ugyan egyelöre elmaradnak például a japán és dél-koreai szintektől - hiszen e két országban a K + F-ráfordítás hagyományosan magas, még a fejlett országokhoz képest is -, de a kínai adat közel azonos szinten van az Európai Unió, Ausztrália vagy Szingapúr GDP-arányos ráfordításaival.

Bár a kormányzati politikák és a hazai szabályozási környezet közötti különbségek megnehezítik a szabadalmi bejelentések és az országok közötti támogatások összehasonlítását, érdemes megjegyezni, hogy a Szellemi Tulajdon Világszervezetének (World Intellectual Property Organization, WIPO) adatai alapján 2016ban a szellemi tulajdon bejegyzésért felelős kínai hivatal (China's State Intellectual Property Office, SIPO) a világ összes szabadalmi bejelentésének 42,8 százalékát dolgozta fel. Az 1,3 milliónál is több bejegyzéssel Kína több mint kétszer annyi bejelentést dolgozott fel, mint az Egyesült Államok, négyszer annyit, mint Japán, és hatszor annyit, mint Dél-Korea. ${ }^{7}$

Végezetül, a kínai innováció kapcsán érdemes megnézni Kína magas technológiájú exportjának alakulását is (10. ábra). Felipe és szerzőtársai [2012] szerint minél inkább

\footnotetext{
${ }^{7}$ Meg kell jegyeznünk ugyanakkor, hogy a kínai rendszer távolról sem tökéletes: a sok szabadalmi bejegyzés egyik fő oka a külföldi szabadalmak bejegyzése, a másik pedig, hogy a műszaki területen tevékenykedő doktoranduszhallgatók csak abban az esetben szerezhetik meg a fokozatot, ha „feltalálnak" valamit, akármilyen haszontalan vagy épp plagizált dolog legyen is az.
} 
9. ábra

Kína K+F-kiadásai a GDP százalékában, 1996-2016

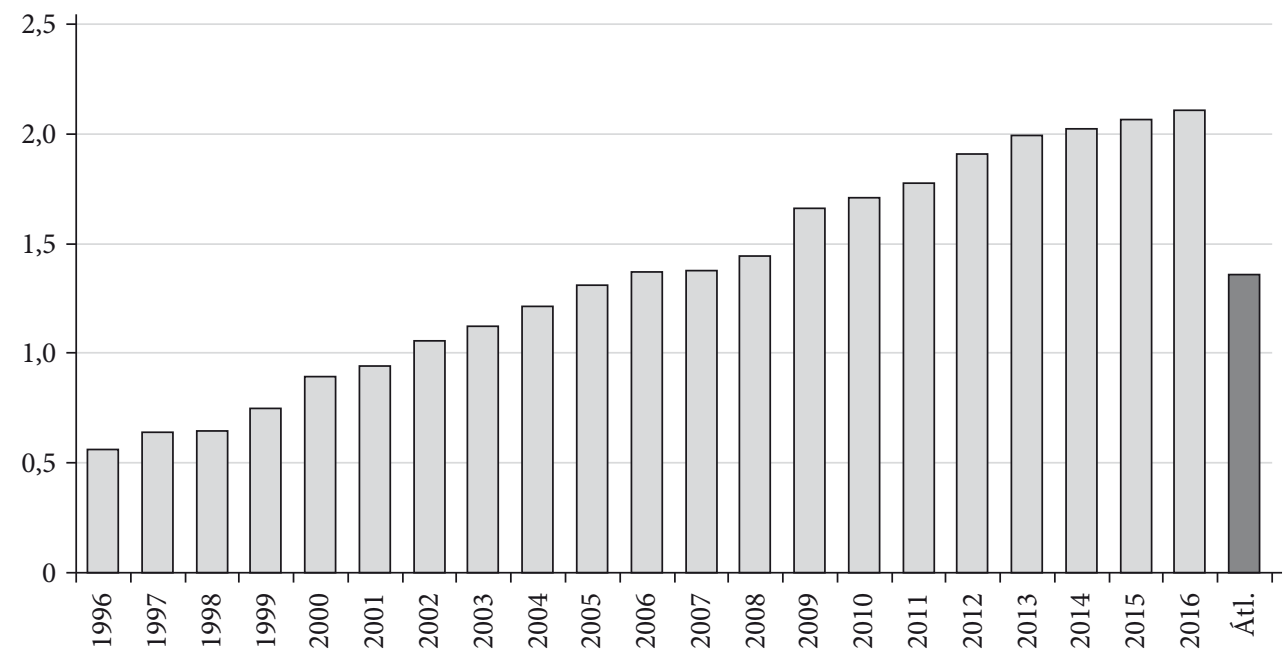

Forrás: Világbank.

diverzifikált egy ország exportja, minél inkább képes finomra hangolt termékeket elöállítani és exportálni, annál nagyobb a fejlődés valószínűsége, szemben azon országokkal, amelyek csak egy adott szektorban tudnak felmutatni eredményeket. A szerzők Dél-Koreát hozzák fel példaként, amely több szektorban is sikeres exportőrré tudott válni, ellentétben például a ma is közepes jövedelmü Fülöp-szigetekkel vagy Malajziával, amely országok csak az elektronika bizonyos szegmenseiben értek el sikereket. Eichengreen és szerzőtársai [2013] elemzése szerint a csúcstechnológiájú termékeket elöállító országok között ritkábban tapasztalható növekedési lassulás, de Felipe és szerzőtársai [2012] is arra jutott, hogy a közepes jövedelmi csapdát elkerülő országok jellemzően relatíve diverzifikáltabb, kifinomultabb exportkosárral rendelkeztek.

Ami tehát a kereskedelmi struktúrát illeti, Kína továbbra is versenyképes számos, alacsony költségű, munkaigényes termék gyártásában, ennek eredményeként az így előállított termékek is jelentős részét képezik a kínai exportnak. Ebből eredően, bár Kína legnagyobb exporttermékei az elektromos gépek és berendezések, a kínai exportkosárban továbbra is jelentősebb tételt képviselnek a fémek, bútorok és különböző textiltermékek.

A legfrissebb (2017-es) kínai adatok alapján a feldolgozóipari export közel 24 százalékát már a magas technológiájú termékek kivitele adja. Ez az arányszám magasan a világátlag (16 százalék) felett áll, és meghaladja a fejlett országok mutatóit is (az Egyesült Államok, az Európai Unió és Japán esetében egyaránt 13-14 százalék közelében van ez az érték).

Ezt az adatot is érdemes ugyanakkor fenntartásokkal kezelni, mivel Kínában a csúcstechnológiai iparágakban viszonylag alacsony a hazai hozzáadott érték, és a kínai csúcstechnológiai export sok esetben a Kínában megtelepült külföldi tulajdonú vállalatoktól származik (lásd erről részletesebben később a 12. ábrát). 
10. ábra

A kínai magas technológiájú export a feldolgozóipari export százalékában, 1988-2016

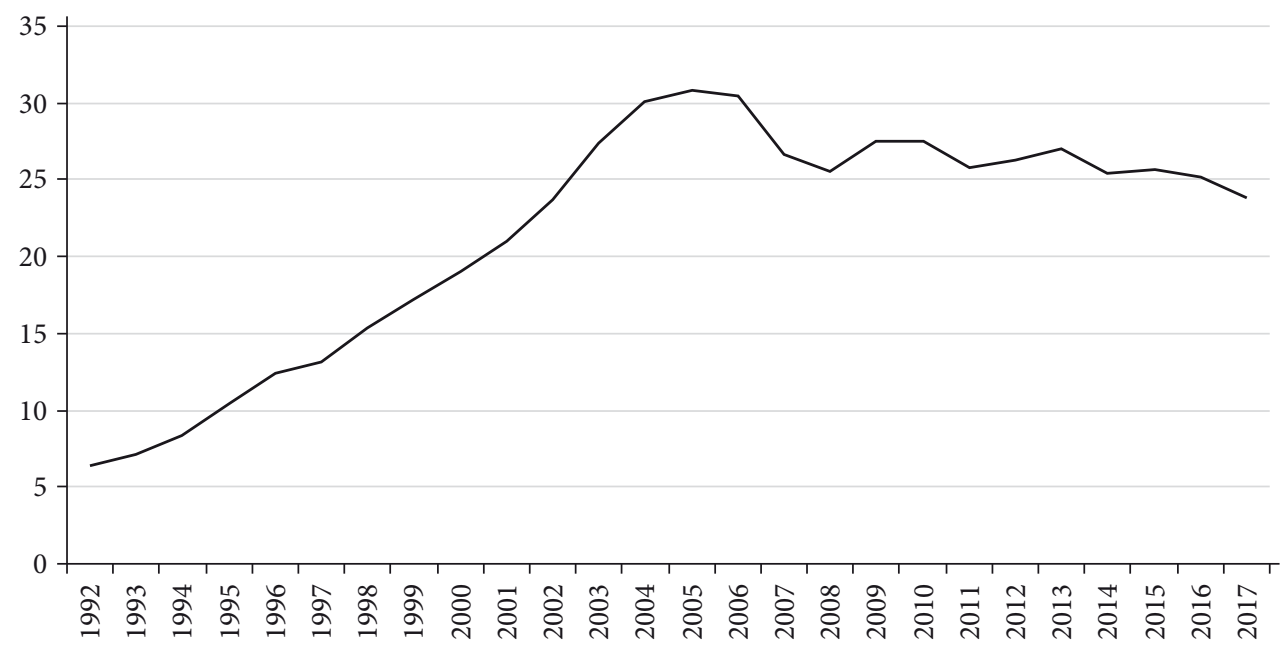

Forrás: Világbank.

Szemléletes példa erre Dedrick és szerzőtársai [2010] elemzése néhány Kínában összeszerelt csúcstechnológiai exporttermék (például az Apple iPodja) esetéről. A szerzők vállalati mérlegadatokra, éves jelentésekre, iparági adatbázisokra, elemzésekre és kereskedelmi adatokra támaszkodva kiszámolták, hogy az iPod értéklánca hogyan épül fel, mennyibe kerülnek a beépített alkatrészek, hol gyártják ezeket, mekkora a kereskedelmi árrés, az egy termékre vetített szállítási költség stb. Arra jutottak, hogy az iPod kiskereskedelmi árán belül az összeszerelés - az ennek során elvégzett minőségi ellenőrzéssel együtt - alig több mint egy százalékot tesz ki, hozzáadottérték-alapon pedig Kína részesedése maximum két-három százalék. A helyzet ma már ugyan a 2009-es helyzetnél kedvezőbb, de a kínai hozzáadott érték a kínai csúcstechnológiai export értékével összehasonlítva továbbra is rendkívül alacsony.

\section{Modernizációs stratégiaváltás Kínában - „tervgazdaság” az innováció szolgálatában?}

Kínára éveken át az utánzás és másolás egyik fő letéteményeseként tekintettek világszerte. A kelet-ázsiai óriást folyamatosan érték - és érik - azok a vádak, amelyek szerint legjobb ötleteit, „innovációit” a Kínában megtelepült külföldi vállalatoktól vagy a szellemi tulajdonjogok megsértésével, vagy ipari kémkedés révén szerzi be. Míg tehát Kína nagy volumenü, alacsony költségű gyártási készségét soha nem kérdőjelezték meg, addig az alapvetés mindig is az volt, hogy az innováció terén az ország versenyképessége minimális. Ahogy azonban a fentiekben már utaltunk rá, Kínában az innováció terén is jelentős volt a fejlődés az elmúlt évtizedben, és az ország a 21. 
századra valódi innovációs tényezővé vált: vezető szerepet tölt be számos új technológia terén, a kínai kormányzat stratégiai terveinek megvalósításával nemzetközi szinten is innovációs nagyhatalommá válhat.

Az innovációs nagyhatalommá válás folyamatának egyik fontos alapja a „Made in China 2025” (MiC25), egy tízéves, grandiózus iparfejlesztési terv, amely a kínai gazdaság strukturális átalakításának részeként a munkaigényes termelésről a tudásintenzív gyártásra történő átállást tüzte ki céljául. ${ }^{8}$

A „Made in China 2025” programot a Kínai Népköztársaság Államtanácsa 2015 májusában hirdette meg, válaszul a globális újraiparositási hullámra, illetve Németország ipar 4.0 stratégiájára. A programot a nemzeti fejlesztési és reformbizottság (National Development and Reform Commission, NDRC), a tudományos és technológiai minisztérium (Ministry of Science \& Technology, MOST) és az ipari és információs minisztérium (Ministry of Industry and Information Technology, MIIT) közösen dolgozták ki. Átfogó jellege ellenére a MiC25 a nagyszámú innovációorientált fejlesztési stratégia egyike csupán, mint alább bemutatjuk, a számos kapcsolódó fejlesztési terv között önálló stratégiaként szerepel a mesterséges intelligencia fejlesztése és elterjesztése.

A program napjainkra a vállalatok és önkormányzatok müködését koordináló, azokat a nemzeti prioritásokkal összehangoló eszközzé, mindezek révén pedig az ipari fejlesztések erőteljes katalizátorává vált. Az átállást párhuzamosan, több szinten (iparági, technológiai, regionális) valósítják meg.

Az első szint a stratégiainak tekintett iparágak fejlesztése. ${ }^{9}$ A MiC25 tíz iparágat emel ki, illetve kezel prioritásként, ezek a következők: az újgenerációs információs technológia; a csúcsminőségű számítógép-vezérlésủ gépek és az automatizálás; a repülési és ürjárművek/-berendezések; a tengerészeti mérnöki berendezések és csúcstechnológiájú hajók; a vasúti berendezések; az energiatakarékos jármüvek; az új anyagok; a biomedicinák és a nagy teljesítményü orvosi készülékek; az energetikai berendezések; valamint a mezőgazdasági berendezések ( $L i$ [2018]). Az átfogó iparfejlesztési tervet számos iparági és technológiai szintű fejlesztési terv és forgatókönyv egészíti ki és konkretizálja (11. ábra).

\footnotetext{
${ }^{8}$ A tízéves terv csupán az első fázisa egy nagyobb, három fázisból álló fejlesztésnek, amelynek eredményeként Kína a világ összeszerelő mühelyéből egy innovatív termelési technológiákat használó, önálló - azaz külföldi ellátási láncokat és technológiát nem igénylő - gyártóhatalommá válik, legalábbis a kínai vezetés elképzelései szerint. A program a Kínában gyártott termékek minőségének javítására összpontosít, illetve saját márkák létrehozását ösztönzi, stabil gyártási képességek és a legmodernebb technológiák kifejlesztése révén. Az első fázis a 2015-2025 közötti tízéves időszakot öleli fel, amelyben az elsődleges cél, hogy Kína bekerüljön a legnagyobb globális gyártóhatalmak közé. A második fázis a 2026-tól 2035-ig terjedő időszak, amikor is Kína e gyártóhatalmak között - teljesítményét tekintve - megközelíti a dobogót. A harmadik fázis, azaz a 2036 és 2049 közötti időszak végére pedig - amikor a Kínai Népköztársaság fennállásának 100. évfordulóját ünnepli - Kína a világ ve zető gyártóhatalmává válik ( $L i$ [2018]).

${ }^{9}$ Ebben a tekintetben a MiC25 a japán, dél-koreai, szingapúri és tajvani fejlődési utakat követi, hiszen a stratégiai ágazatokra épülő iparpolitikával e kelet-ázsiai országok is sikeresen törtek ki az alacsony technológiai színvonalú, munkaigényes gyártás (összeszerelés) csapdájából.
} 
11. ábra

Kínai nemzeti szintű cselekvési és fejlesztési tervek száma, 2015-2018

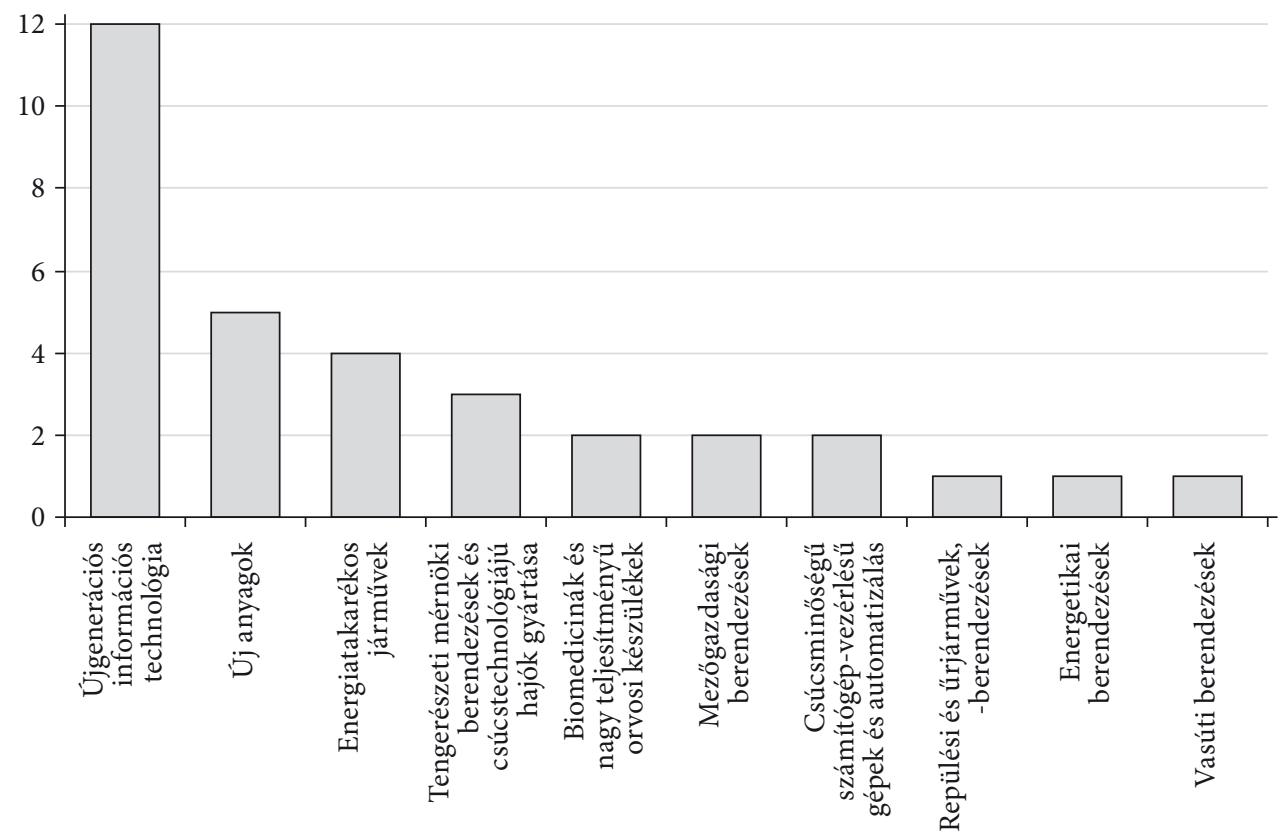

Forrás: The Mercator Institute for China Studies (MERICS) (Zenglein-Holzmann [2019] 21. o.).

Az iparági programokkal szorosan összefonódva jelennek meg a technológiai programok (második szint), ${ }^{10}$ kiemelten a fejlett ipari technológiák (intelligens gyártás) és a mesterséges intelligencia fejlesztése, ami nem meglepő, hiszen ezek minden iparágban jelen lévő, termelékenységüket erőteljesen befolyásoló technológiák (Szalavetz [2017], [2019]). ${ }^{11}$

${ }^{10}$ Ezek egyike a 2015-ben - Li Ko-csiang miniszterelnök személyes kezdeményezésére - meghirdetett „Internet Plus” program. Ez valójában egy modern ötéves terv a felhőalapú számítástechnika, a nagy adatmennyiség (big data) és a dolgok és szolgáltatások internete (Internet of Things, IoT) különféle iparágakkal történő integrálására, a gyártástól a kereskedelmen át az internetes bankolásig, a kormányzati ügyintézéstől az egészségügyig vagy épp a mezőgazdaságig. A program célja, hogy Kína növekvő gazdaságát összekapcsolja, ha úgy tetszik, „felturbózza” az internetes szolgáltatások erejével (Zhao [2019] 180. o.). A föbb célkitüzések többek között: 1. több forrás biztosítása kutatásra és fejlesztésre, 2020-ig elérve a GDP 2,5 százalékát; 2. a külföldi technológiai innovációktól való függőség csökkentése; 3. $100 \mathrm{MB} / \mathrm{s}$-os internetkapcsolat biztosítása a nagyvárosok lakói számára; 4. széles sávú kapcsolat lehetősége a lakosság 98 százalékának; 5. további finanszírozás az üzleti fejlődés és az innováció előmozdításához (Chang [2016]). Kínai források szerint az itt említett célkitűzések közül már több meg is valósult: a kormányzati intézkedéseknek köszönhetően az internethez való hozzáférés sokat javult, a kapcsolat gyorsabb és olcsóbb lett, miközben számos akadályozó politikát is felszámoltak (State Council [2018]).

${ }^{11}$ Ami a fejlesztések volumenét illeti, 2018 végéig 530 intelligens gyártási technológiával mủködő ipari park létesült az országban (Zenglein-Holzmann [2019]). Legtöbbjük nagy adatmennyiség (big data) feldolgozására összpontosít, de az új anyagok és a felhőalapú számítástechnika (cloud computing) is kiemelkedő szerepet játszanak (Woo [2017]). 
Az államtanács 2017-ben hirdette meg a következő generációs mesterséges intelligencia fejlesztésére vonatkozó programot (Next Generation Artificial Intelligence Development Plan, NGAIDP), kiemelve, hogy a nemzetközi versenyhelyzet mellett a nemzetbiztonsági kihívások is indokolják a mesterséges intelligencia nemzeti stratégiaként történő megfogalmazását. Várakozásaik és az NGAIDP-ben foglaltak szerint a mesterséges intelligencia átfogó fejlesztése - az elméleti modellezés, a technológiai innovációk, valamint a szoftver- és a hardverkorszerüsítések stb. révén - láncreakciót vált ki, ami felgyorsítja a gazdasági és társadalmi fejlődést. Az NGAIDP a mesterséges intelligencia fejlesztése szempontjából háromlépcsős politikát határoz meg az iparra, a technológiára és az alkalmazásokra vonatkozóan. Az ipar esetében elsősorban a gépi tanulásra, az intelligens csipekre és a felhőalapú tárolásra koncentrál, ${ }^{12}$ a technológiák terén a dolgok és szolgáltatások internete (Internet of Things, IoT), a big data, a mesterséges intelligencia és az intelligens gyártás kerül középpontba, míg az alkalmazás terén a földrajzi információs rendszer, az intelligens hálózat, az intelligens mezőgazdaság, az információbiztonság és a precíziós orvostudomány szerepel kiemelten. A terv az egyetemi és posztgraduális oktatásban is komoly szerepet szán a mesterséges intelligenciának: MI-tudományágat, MI-szakokat említ, sőt MI-re specializálódott főiskolák alapítását is szorgalmazza (CISTP [2018]).

A harmadik szint a regionális, pontosabban a kiemelt övezetek és városok szintje. A program megvalósítása során a kínai vezetés merít a korábbi tapasztalatokból is: a „reform és nyitás” 1978-as meghirdetésekor is úgynevezett különleges gazdasági övezetekben „tesztelte” a szabadpiaci mechanizmusok és az állami tervezési politika együttes működését. A kijelölt városok mellett (elsőként egy délkelet-kínai kikötővárost, Ningbót jelölték ki), az országos szintü stratégiával összhangban, a jelentősebb helyi önkormányzatok saját tartományi és városi szintű ipari és MI-központú technológiai fejlesztési programokat (az európai „intelligens szakosodási stratégiához" hasonló stratégiákat) és pontos célokat tartalmazó fejlesztési forgatókönyveket (roadmap) fogalmaztak meg, ami egyúttal a helyi szintủ vezetés központi forrásokért történő versengésének is eszköze lett.

Peking mellett - amely például egy kétmilliárd dolláros, 400 MI-vállalkozás befogadására képes MI-fejlesztési parkot is tervez - Sanghaj és Tiencsin is az élenjáró városok közé tartozik a mesterséges intelligencia fejlesztésében. A korábbi halászfalut, Sencsent ma már a kínai Szilícium-völgyként emlegetik. Itt van a székhelye többek között az információtechnológiára, személygépkocsikra és a megújuló energiára specializálódott BYD vállalatnak, a két telekommunikációs óriásnak, a Huaweinek és a ZTE Corporationnek, továbbá az internetes szolgáltatásokat kínáló Tencentnek és a genomszekvenálással foglalkozó Beijing Genomics Institute-nak is. Sencsent és környékét, azaz a Gyöngy-folyó deltáját kínai tervek szerint megapolisszá alakítják Greater Bay Area néven, amely a kínai nemzeti stratégiai fejlődési terv kulcsszereplöje lett (Ketchum-Cheng [2018]). De

${ }^{12}$ A program nevesíti a mesterséges intelligencia önállóan fejlesztendő iparági alkalmazásait (intelligens, összekapcsolt járművek, robotika, videomegfigyelési rendszerek, az intelligens otthonok termékei), az ezek gyártásához szükséges, mesterséges intelligenciát integráló ipari berendezéseket és logisztikai megoldásokat, valamint a fejlesztést támogató infrastruktúrát (5G rendszerek, kiberbiztonsági megoldások). 
az eddigieken túl említést érdemel még Hangcsou, az Alibaba-csoport székhelye is. A szolgáltató szektor részaránya itt már 2016-ban is 60 százalék feletti volt, és az infokommunikációs iparágak is rendre két számjegyü növekedést produkálnak, miközben a már említett „Internet Plus” elnevezésű program végrehajtása is itt a legsikeresebb, megelőzve Pekinget és Sanghajt is. Hangcsoutól két kilométerre található az Álomváros (Dream Town) néven ismert hely, ahol az induló internetes vállalkozásoknak legalább három évig biztosítanak ingyenes irodahelyiséget és infrastruktúrát. A kezdeményezés 2015-ben indult, az első két évben több mint 7000 vállalkozás dolgozott itt több mint 700 projekten (Zhao [2019] 182. o.).

A program - összhangban az utóbbi időszak kínai stratégiáival, nem egy vagy több konkrét utasítás halmaza, sokkal inkább iránymutatás, amely folyamatosan képes alkalmazkodni az újonnan felmerülő kihívásokhoz, miközben a főbb célkitűzések - a nemzeti technológiai képességek korszerűsítése és a technológiai ugrás lehetőségeinek megteremtése - változatlanok maradnak.

A fenti adatok tanúsítják, hogy a MiC25 ma már nem csupán terv, hiszen a program végrehajtása négy éve megkezdődött, sok milliárd dollár állami finanszírozással.

A finanszírozás összegét ugyanakkor nehéz pontosan felbecsülni, mert a vállalatok a közvetlen juttatásokon kívül több más csatornán keresztül is hozzáférhetnek a támogatásokhoz. Támogatást kaphatnak adókedvezményként vagy különböző (állami, tartományi vagy állami vállalatok/bankok által létrehozott) fejlesztési alapoktól, ${ }^{13}$ de akár a kísérleti és demonstrációs programok, kiemelt projektek, illetve az ipari és technológia parkok vagy a speciális övezetek közvetlen állami finanszírozása révén is. Az állam közvetett támogatást nyújt a könnyített kis- és középvállalati finanszírozási programokkal, illetve a kockázati tőkebefektetések állami vagy tartományi támogatásával (Zenglein-Holzmann [2019]).

A program végrehajtása az elmúlt két évben kapott igazi lendületet. ${ }^{14}$ A Mercator Institute for China Studies (MERICS) friss jelentésében kiemeli, hogy - bár az előrehaladás mértékét a MiC25 átfogó és adaptív jellege miatt nehéz megbecsülni - Kína jelentős eredményeket tudhat magáénak (Zenglein-Holzmann [2019]).

Bár a fent sorolt tíz kiemelt ágazat tekintetében az előrehaladás távolról sem kiegyensúlyozott, az ország már látványosan előrelépett olyan területeken, mint az $5 G$ hálózatok, a nagy sebességü vasutak és az ultramagas feszültségü villamosenergia-átviteli rendszerek fejlesztése vagy a termelés robotizációja. Ami ez utóbbit illeti, számos iparágban Kína nem csupán a világátlag felett teljesít, de már legalább annyi robotot használ, mint fejlett országok, sőt, az International Federation of Robotics adatai szerint az autóipar területén már valójában többet, mint Japán vagy DélKorea, míg az elektronika területén többet, mint az Egyesült Államok vagy Németország (idézi Cheng és szerzőtársai [2019]). 2017-ben az összes újonnan üzembe helyezett robot 41,01 százaléka Kínába került (az International Federation of Robotics statisztikáit idézi Dewan [2018]), ennél még inkább szembetűnő a robotgyártás

\footnotetext{
${ }^{13}$ Zenglein-Holzmann [2019] adatai szerint 2018 tavaszán több mint 1800 állami ipari beruházási alap működött Kínában összességében 3000 milliárd jüan forrással.

${ }^{14}$ Igaz, a körülmények nem feltétlenül voltak ideálisak: a gazdasági növekedés lassulása folyamatos kihívást jelent, és a kínai-amerikai kereskedelmi háború sem teremtett kedvező feltételeket.
} 
növekedése Kínában: Cheng és szerzötársai [2019] szerint 2012-ben még csak körülbelül 5800 robotot gyártottak, 2017-ben azonban már 131000 darabot, amelynek közel 30 százalékát már helyi, azaz nem az országban megtelepült külföldi, hanem kínai cégek állították elő. A robotok gyártásával vagy a robotika kutatásával foglalkozó cégek száma is gyorsan növekszik: a kínai állami és ipari kereskedelmi igazgatóság (State Administration for Industry and Commerce, SAIC) adatai szerint a kétezres évek elején néhány száz cég foglalkozott robotokkal, ma viszont már közel hétezer. E fejlődés a robotikai szabadalmak számának növekedésében is tetten érhetö: a korábban már említett, kínai szellemi tulajdonjogok bejegyzésével foglalkozó SIPO mindössze 54 innovációs szabadalmat adott ki a robotika területén 2000-ben, 2010ben viszont már 319-et, 2015-ben pedig 1145-öt.

A stratégiai iparágak hazai innovációra támaszkodó fejlesztését elősegíti a hatalmas belső piac: a kínai kormány nem csupán pénzügyi támogatással, hanem a kereslet mesterséges megteremtésével ösztönzi a jövőbeli technológiák kifejlesztését, többek között kedvező szabályozások vagy adókedvezmények révén (Shi-Kupfer-Ohlberg [2019]).

Mindazonáltal Kína digitalizációs és a mesterséges intelligencia fejlesztésére építő stratégiája számos belső és külső kihívással szembesül. A politikai gazdaságtan szemszögéből nézve hazai színtéren az egymással ellentétes célok és döntéshozói érdekellentétek okoznak feszültséget, míg a magánvállalkozások fölötti fokozott állami kontroll és a tőke nem hatékony elosztása ugyancsak rizikófaktor (Shi-Kupfer-Ohlberg [2019]). Ami pedig a külső kihívásokat illeti, Kína még jó ideig függni fog a külföldi alaptechnológiáktól, amit jól példáz a kínai-amerikai kereskedelmi vádaskodás előbb a ZTE, majd a Huawei ellen indított fejezete. A ZTE majdnem csődbe ment, miután az Egyesült Államok azzal fenyegetőzött, hogy betiltja a mikrocsipek eladását a távközlési szolgáltatónak, míg a Huawei majdnem operációs rendszer nélkül maradt a vállalatra kirótt - majd részben visszavont - amerikai szankciók miatt. Az előbbieken túl Kína a félvezetők tekintetében is még mindig az Egyesült Államoktól függ. Kína azonban felismerte az e függőségekben rejlő kihívásokat, és ennek megfelelően is cselekszik az utóbbi években. A Huawei már évek óta fejleszti saját - az Androidhoz némiképp hasonló - operációs rendszerét, a félvezetők tekintetében pedig a behozatalt az eddigiek felére kívánja csökkenteni a következő években, hosszú távon teljesen megszüntetve.

Ahogy a fentiekből is jól látható, a mesterséges intelligencia gyakorlatilag néhány év leforgása alatt a kínai vezetők első számú prioritásává vált: ma Kína nem titkolt célja, hogy a világ vezető MI-hatalmává váljon, ennek érdekében 2030-ig 150 milliárd dollárt költ erre az iparágra, amelynek úttörője ráadásul egyértelmüen a magánszektor (Horowitz és szerzőtársai [2018]). Meg kell jegyeznünk ugyanakkor, hogy Kína digitalizálás iránti törekvése túlmutat a gazdasági ambíciókon: a hatékony kormányzás, illetve a vállalatok és a lakosság ellenőrzése is fontos szempontok, amelyek megvalósítására a kínai vezetésnek megfelelő eszköztár áll a rendelkezésére. Ezt szolgálja a „társadalmi kreditrendszer” - egy országos digitális ellenőrző rendszer, amely a törvények, rendeletek vagy a pártállami célok érvényesítését a vállalatok és magánszemélyek pontozásával éri el -, amelynek kiépülése folyamatban van. A gazdasági és társadalmi hasznosításon túl a mesterséges intelligencia katonai célú felhasználása sem idegen a rendszertől. 


\section{Kínai vállalatok és a digitális átalakulás - állami és/vagy magánszektor?}

Az Alibaba-vezér Jack Ma a digitális gazdaság hatásaira vonatkozó kutatások elömozdítására hozta létre a Luohan Academy nevü szervezetet. Az akadémia Digitális technológia és inkluzív növekedés címü 2019-es jelentése jól tükrözi a digitalizációval kapcsolatos kínai álláspontot (Luohan Academy [2019]). A jelentés egyik fö gondolata, hogy a digitális technológia az inkluzív növekedés fontos hajtóereje lehet, de utal arra is, hogy a digitalizáció terjedéséhez, hatékonyságának növekedéséhez szoros partnerségre van szükség az állami és a magánszektor között. Mivel a kínai gazdaság egyik sajátossága az állami tulajdonú vállalatok jelenléte, érdemes megvizsgálni e vállalatok - illetve magántulajdonban lévő társaik - szerepét a $\mathrm{K}+\mathrm{F}$-források felhasználásában, illetve a digitális átalakulásban.

A MiC25, a digitalizáció és a mesterséges intelligencia fejlesztését célzó kínai programok elemzői, értékelői egyöntetűen kiemelik, hogy e programok megvalósítását nem csupán az állami akarat, valamint a központi és helyi források hajtják előre: a program a magánszektor erőteljes bevonásával valósul meg. Sőt a fejlesztési tervek kiemelt szerepet szánnak az innovatív magánvállalkozásoknak és a technológiai cégeknek.

A globális vállalkozási és fejlődési index (Global Entrepreneurship and Development Index, GEDI) mutatói jól jelzik a vállalkozási teljesítmény fejlődését. A 2012-es (20102011-es adatok alapján készült) GEDI mutató szerint Kína az 58. helyezett volt a globális rangsorban: Venezuela és Algéria között helyezkedett el. Az intézményi és egyéni változókat összesítő pillérek közül a technológiai szektor tekintetében mutatta a legnagyobb lemaradást (Ács-Szerb [2012]). Ez a pillér az összetett GEDI index három alindexe közül a „vállalkozói képességek” alindexbe tartozik: ide olyan pillérek tartoznak, mint a verseny erőssége (a piaci dominancia mértéke), az emberi erőforrás minősége, a technológiai szektor jelentősége, valamint az úgynevezett lehetőségmotivált vállalkozásindítás. A másik két alindex a „vállalkozói attitűdök” és a „vállalkozói aspirációk" alindexe (lásd erről Komlósi és szerzőtársai [2014]). A 2018-as GEDI index (2015-2016-os adatok alapján) már a 43. helyre sorolja Kínát: ezzel Olaszország és Lettország között helyezkedik el. Minden egyes alindex esetében felsorolják a 25 legjobban teljesítő országot: Kína 2018-ban a vállalkozói aspirációk alindexén belül már bekerült az élvonalba (24. hely). Ez az alindex egyebek mellett a vállalkozások innovativitását, gyors növekedési és nemzetköziesedési képességét, valamint a kockázatitőke-finanszírozás állapotát méri fel.

Az innovatív magánvállalkozások fejlődését tükrözi a kínai márkák számának és világpiaci jelentőségének növekedése is. A kínai saját márkás termékek számának növekedését eseti példákkal lehet illusztrálni, az összes exportból való részesedésük növekedésére pedig közvetett adatok alapján következtethetünk. Erre utal, hogy a Fortune 2019. évi listáján ${ }^{15}$ már 119 kínai cég található, közöttük olyan „saját márkás" iparágak képviselői is, mint a számítógépek, telekommunikációs eszközök,

\footnotetext{
${ }^{15}$ https://fortune.com/global500/2019.
} 
ipari berendezések, textiltermékek és járművek gyártása, továbbá technológiai és gyógyszeripari cégek.

A gyorsan növekvő, egymilliárd dollárt meghaladó értékü kínai technológiai vállalatok, azaz az unikornisok száma mutatja, hogy a digitális átalakulás és a mesterséges intelligencia fejlesztése terén elért eredmények elsősorban a kínai magánvállalatok tevékenységére vezethető vissza. 2019. augusztusában 391 unikornist tartottak nyilván a világon ${ }^{16}$ (számuk hónapról hónapra nő). E vállalatok többsége amerikai, de a kínai cégek száma olyan gyors ütemben nőtt, hogy Kína már évek óta a második helyezett a listán (2019 augusztusában 201 amerikai és 97 kínai unikornis szerepelt a listán). ${ }^{17}$ E startupok finanszírozása is hihetetlen mértékben növekedett az elmúlt években Kínában. 2017-ben az induló MI-vállalkozások globális sajáttőke-finanszírozásának 48 százaléka már Kínában összpontosult, míg az Egyesült Államokba csupán 38 százalék jutott. Különösen jelentős növekedés ez 2016-hoz képest, amikor Kína a globális MI-finanszírozás csupán 11 százalékát képviselte (Mitchell [2019]).

A technológiai óriásvállalatok hatalmas összegeket fektetnek kutatás-fejlesztésbe. Az internetalapú szolgáltatások és termékek előállítására, valamint a mesterséges intelligencia fejlesztésére szakosodott, pekingi székhelyü Baidu például különösen aktívan képviseli az „MI az első” napirendet: 2013-ban létrehozta az Institute for Deep Learning nevü kutatóintézetet, 2014-ben pedig MI-labort alapított a Szilícium-völgyben.

A vállalati szektor szerepének értékelésekor természetesen abból kell kiindulnunk, hogy Kínát vállalati döntéshozatali szempontból a felülről lefelé irányuló etatizmus és egy erős, alulról felfelé irányuló mechanizmus keveréke jellemzi. Kínában ugyanis a központi intézmények helyi változatai - sőt az informális intézmények - gyakran felülírják a hivatalos intézményeket, $\mathrm{s}$ a sikeres példák, intézményi innovációk hamar elterjednek a különböző településeken. Az informalitás, valamint a személyes kapcsolatok hálója (kuanghszi/guangxi) szintén fontos szerepet játszanak a döntéshozatalban. Mivel a kínai vállalatirányítás a felülről lefelé és az alulról felfelé irányuló irányítás keveréke, így több üzleti rendszer egyidejü jelenlétével jellemezhető.

A veszteséges és hatékonytalanul müködő állami óriások mellett az országban a közelmúltban jelentek meg a nyereségorientált és verseny által vezérelt, állami ellenőrzés alatt álló vállalkozások új formái - például a China Mobile -, miközben számos magánvállalkozás és állami-magán hibrid - mint például a Huawei, a Lenovo vagy a Geely - lett sikeres hazai és nemzetközi piacokon egyaránt. E nem állami, de politikailag támogatott nemzeti vállalatokat "nemzeti bajnokoknak” tekintik a kínai állami vezetők (Naughton [2007], Ten Brink [2013]). Néhány

${ }^{16}$ A teljes listát a CBInsights közli (https://www.cbinsights.com/research-unicorn-companies).

${ }^{17} 75$ milliárd dollárral rögtön a lista élén áll például a kínai MI-iparág egyik éllovasa, a Toutiao, amely személyre szabott sajtóhíreket ajánl a közösségi média felhasználóinak az általuk meghatározott érdeklődési területek, illetve böngészési szokásaik alapján. A lista 56 milliárd dollárt érő második helyezettje is kínai, a Didi Chuxing Technology Co., amely applikációalapú szállítási szolgáltatásokat (taxiszolgáltatás, autó-, motor- és kerékpármegosztás stb.) biztosít Latin-Amerikától Ausztráliáig. A lista összesen 15 - tízmilliárd dollárt meghaladó értékű - dekakornisa közé befért még egy kínai vállalat, a 12 milliárd dollár értékủ Bitmain Technologies, amely alkalmazásspecifikus integrált áramköri (ASIC) csipeket tervez bitcoinbányászathoz. A „csupán” kereken tízmilliárd dollárt érő vagy egy- és tízmilliárd dollár közötti értékű unikornisok között több mint 90 kínai tulajdonú további vállalatot találunk. 
kivételtől eltekintve - mint például az információtechnológiai szektor, amely már mélyen integrálódott a globális termelési hálózatokba - a legtöbb iparágban a nemzeti (állami irányítású, hibrid- és magán-) tőke dominál, és nem a külföldi multinacionális vállalatok (Nölke és szerzőtársai [2015]).

A kínai digitális stratégiát különösen szívén viseli a kormányzat (sőt Hszi Csin-ping elnök személyesen is): a nemzeti informatizációs stratégia (National Informatization Strategy, 2016-2020) felhívja Kína internetes vállalatait, hogy külföldi piacokon is támogassák a „digitális selyemút” létrehozását, a már említett MiC25 mellett pedig az „Internet Plus” program is 2015-ben indult a hazai ipari és a digitális innováció ösztönzésére. Az állami és a magánszféra közötti kapcsolat az infokommunikációs technológiák (ICT) terén valóban egyedülálló. Kína informatikai nemzeti bajnok vállalatai - a Baidu, az Alibaba, a Tencent, a Jindong és a NetEase - gyakorlatilag laboratóriumi körülmények között fejlődhettek, mert a kínai vezetés blokkolta a külföldi versenytársakat, miközben nem csupán megengedte, hanem támogatta is e vállalatok nemzetközi terjeszkedését és külföldi tőkéhez való hozzáférését a tengerentúli tőzsdei jegyzések révén.

Mindeközben a külföldi vállalatoknak Kínában valóban nehéz „labdába rúgniuk”. Az eBay 2002-ben jelent meg Kínában, és gyorsan 70 százalékos piaci részesedésre tett szert. Öt évvel később piaci részesedése 10 százalék alá csökkent. 2004-ben az Amazon felvásárolt egy kínai online könyvkereskedőt. A piaci részesedése 2008-ban 15 százalék volt; most 1 százalék alatt van. 2005-ben jelent meg a kínai piacon a Microsoft MSN-szolgáltatása, és 53 százalékos piaci részesedést szerzett a kínai üzleti felhasználók körében. 2014 októberében lépett ki a kínai piacról, addigra ugyanis részesedése 5 százalék alá csökkent a Tencent QQ és a WeChat által teremtett versenyben. Az Uber 2014-ben jelent meg Kínában, milliárdokat költött, hogy piaci részesedést szerezzen a kínai versenytársaktól. Végül 2016-ban eladta kínai leányvállalatát egy helyi vállalatnak, és kilépett az országból. 2015-ben az Airbnb is megjelent Kínában, de soha nem tudta igazán felvenni a versenyt a kínai versenytársakkal: 2017-ben az Airbnb 150 ezer kiadó szobát kínált, míg a piacvezető Tujia.com 650 ezret (Li és szerzőtársai [2018]).

A ZTE - a nagy állami távközlési berendezéseket gyártó vállalat - esetében az állami atyáskodás még ennél is egyértelmübb a kormányzati finanszírozás és preferenciális beszerzések miatt. A 2018-ban kirobbant botrányt követően sokan a Huaweit is ebbe a kategóriába sorolják, a magántulajdonban lévő vállalat ugyanakkor tagadja, hogy állami szubvencióknak köszönhetné felemelkedését. Mindazonáltal - konkrét vállalatoktól függetlenül is - szinte lehetetlen nyomon követni a párt vagy a kínai állam befolyását, az állami ellenőrzési mechanizmusokat és a nemzetközi kapcsolatokat, amelyek körülveszik a nemzeti bajnok vállalatokat vagy épp az innovatív induló vállalkozásokat (Shi-Kupfer-Ohlberg [2019]).

Annyi azonban bizonyos, hogy a kínai állami tulajdonú vállalatok továbbra is fontos szerepet kapnak a MiC25-tervhez vagy a digitalizációhoz más módon közvetlenül kapcsolódó stratégiai iparágak fejlesztésében. Azon iparágakat, amelyeket a kínai kormányzat „kulcsfontosságú iparágnak” (például hajóépítés, légi közlekedés, nagy sebességü vasutak) vagy „pillériparágnak” (például elektronika, gépgyártás, autóipar) nyilvánít, 
továbbra is az állami tulajdonú vállalatok fogják dominálni. A MERICS jelentése szerint e két kategóriában 2013 óta az állami tulajdonú vállalatok részesedése a tőzsdén jegyzett társaságok bevételeiből csupán enyhén csökkent: 90 százalékról 83 százalékra a „kulcsfontosságú iparágak” és 53 százalékról 45 százalékra a „pillériparágak” esetében (Zenglein-Holzmann [2019] 45. o.). A MiC25 további prioritásaihoz kapcsolódó területeken - újgenerációs információtechnológia, automatizálás és robotika, energiatakarékos jármüvek, új anyagok, energetikai berendezések, biomedicinák és orvosi készülékek - azonban már ma is a magántulajdonú vállalatok túlsúlya a jellemző.

A fentiekben elsősorban a nagy, nemzetközileg is ismert és elismert kínai vállalatokról esett szó, de - mint az unikornis startupok adatai mutatják - tévedés lenne azt hinni, hogy csupán e vállalatok jeleskednek az innováció és digitalizáció terén Kínában, illetve teremthetnek versenyhelyzetet nemzetközi értelemben is. Valójában több ezer innovatív vállalat van ma az országban, amelyek észrevétlenül felforgatnak számos iparágat, lehagyják a hagyományos szereplőket, és új termékeket, továbbá új üzleti modelleket fejlesztenek ki. Greeven és szerzőtársai [2019] három főbb feltörekvő innovátor vállalattípust különböztet meg, amelyek - ahogy a szerzők írják - egyre nehezebbé teszik a nyugati multinacionális vállalatok számára a kínai vállalatokkal való versengést.

1. A „rejtett bajnokok” (hidden champions) rendkívül specializált cégek, jellemzően iparáguk legjobbjai közé tartoznak, azonban a nagyméretü, világszerte ismert kínai vállalatokkal szemben általában kevésbé ismertek, és bevételeik is ötmilliárd dollár alatt maradnak. E vállalatok célja a hosszú távú növekedés, innovációs tevékenységük pedig folyamatos, termékeiket rendszerint úgy szabják testre, hogy megfeleljenek a globális ügyfelek igényeinek. Greeven és szerzőtársai [2019] több mint 200 rejtett bajnokot azonosított, többek között a gépgyártás, a vegyipar és az elektronika területén.

E típusra jó példa a Lens Technology, Kína legnagyobb - például okostelefon-kamerákban használt - lencsealkatrész-gyártója. Az alapító vállalkozó, Zhou Qunfei eredetileg digitális órák üvegképernyőire specializálódott, de az okostelefonok térhódításával gyorsan felismerte az új lehetőséget. 2003-ban a vállalat a Motorola beszállítója lett, azóta többek között az Apple, a Samsung és számos további okostelefon-gyártó számára biztosítja a képernyőket.

2. Az úgynevezett „technológiai elnyomottak” (tech underdogs) kis- és közepes méretű vállalkozások, amelyek bevétele kevesebb mint 60 millió dollár. Innovatív termékek előállítására specializálódtak, olyan területeken, mint a genetika, a napenergiatechnológia, a mesterséges intelligencia, az új anyagok és az agrártechnológia. E vállalatok alapítói jellemzően a tengerentúlról Kínába visszatérő, amerikai vagy európai elit egyetemeken végzett emberek közül kerülnek ki. Greeven és szerzötársai [2019] kutatásai szerint ilyen vállalkozások tízezrével vannak Kínában. Bár sokuk nem képes túlélni az erős versenyt, néhányuk viszont kiemelkedik, sőt piacvezetővé válik.

A Malong Technologies például a fejlett képalkotó technológiákra specializálódott, amely egy speciális röntgeneljárás segítségével mikroszkopikus szinteket is láthatóvá tesz. Ez a technológia használható a kiskereskedelemben (például önkiszolgáló üzletek, pénztáros nélküli pénztárak), a gyártásban (a hibák észlelése), valamint a közlekedésbiztonsági területeken is (poggyászszkennelés). 
3. A „változást hozók” (change makers) a digitális zavarokból próbálnak meg előnyt kovácsolni. Számos iparágban müködnek, digitális üzleti modelleket alkalmazva, beleértve a médiát és a kiskereskedelmet vagy épp az autó- és kerékpármegosztási szolgáltatásokat. Ellentétben a fent említett két másik típusú szereplővel, az ebbe a típusba tartozó vállalatok jól láthatók, és súlyuk egyre növekszik. Felhasználó-központúak, azaz folyamatosan kommunikálnak a felhasználókkal a közösségi médiacsatornákon keresztül, hogy ennek megfelelően alakítsák termékeiket, üzleti modelljeiket.

A „változást hozók” egyik mintapéldánya a Toutiao, amely személyre szabott sajtóhíreket ajánl a közösségi média felhasználóinak az általuk meghatározott érdeklődési területek, illetve böngészési szokásaik alapján. A mesterséges intelligenciát használó vállalatot 2012-ben alapították, több mint hárommilliárd dollár kockázati tőke támogatásával. A jelentős forrástámogatásnak köszönhetően a Toutiao olyan témákat tudott kínálni, amelyek általában nem szerepelnek a mainstream médiában, miközben igyekezett távol maradni az állam szempontjából kritikus tartalmaktól. 2018 júliusáig a Toutiaónak több mint 120 millió aktív - nagyrészt 30 éves kor alatti - felhasználója volt naponta, főként a fiatalabb korosztály. A vállalat értéke jelenleg több mint 11 milliárd dollár.

\section{Következtetések}

Ahogy tanulmányunkban szemléltettük, a kínai kormányzat a növekedési ütem lassulása és a közepes jövedelmi csapda elkerülése érdekében „digitális nagy ugrást” kezdeményezett. Érveket és adatokat sorakoztattunk fel, hogy bizonyítsuk, a közepes jövedelmi csapda fenyegetése Kína esetében nem egyértelmű: számos jel utal arra, hogy a strukturális átalakulás folytatódik, az intenzív fejlődés sajátosságai fokozatosan, de egyre eröteljesebben mutatkoznak meg.

A modernizációs stratégiaváltás jegyében hosszú távú, átfogó fejlesztési stratégiára támaszkodva, erőltetett ütemben, jelentős volumenủ beruházásokkal, nagyvonalú támogatási programokkal technológiaorientált fejlesztés indult el, amely kiaknázza az új müszaki, gazdasági paradigmát meghatározó technológia - a mesterséges intelligencia - keltette lehetőségeket. Mivel megfigyelök egyöntetű véleménye szerint a digitális átalakulás és az új általános célú technológia átrendezi a világgazdasági erőviszonyokat, Kína a „digitális nagy ugrástól” elsősorban nem a növekedéslassulás problémájának megoldását várja, hanem az eddigi látványos felzárkózásának befejezését, vagyis azt, hogy elfoglalja és stabilizálja helyét a fejlett gazdaságok körében. ${ }^{18}$

A kínai programok és eredmények ismertetése után tegyük fel ismét a kutatási kérdéseinket. Alkalmas-e a feltörekvő iparágak és technológiák szisztematikus fejlesztése a kínai gazdasági növekedés felgyorsítására és a kívánt modernizációs stratégiaváltás megvalósítására? El lehet-e ilyen módon kerülni a közepes jövedelmi csapdát?

\footnotetext{
${ }^{18}$ A digitális átalakulástól várt egyéb, társadalmi, nemzetbiztonsági és geopolitikai célok és azok megvalósítása külön tanulmány tárgya lehetne, ezekkel a kérdésekkel csupán jelzésszerủen foglalkoztunk.
} 
Induljunk ki - a hosszú távú stratégiai fejlesztési programokat készítő kínai kormányzat technokratáihoz hasonlóan - a magas jövedelmü, fejlett országok tudásalapú gazdaságainak néhány jellemvonásából! Ezeket a jellemvonásokat két csoportra oszthatjuk.

1. Az egyikbe a minden gazdasági összehasonlításban szereplő, jól mérhető, de felszíni jelenségek tartoznak, mint amilyen a technológiaintenzív, kutatásigényes, feltörekvő iparágakra történő szakosodás, a fejlett infrastruktúra, a magas technológiai szintet megtestesítő termelésieszköz-állomány, a legújabb technológiát megtestesítő termékek, megoldások széles körü elterjedése vagy a jövőorientált iparágak jelentős világpiaci részesedése.

A kínai stratégiai programok és az ezek eredményességét bemutató tudományos publikációk (például Song és szerzőtársai [2017], Zhao [2019]) az e jellemvonásokat számszerüsítő mutatókra koncentrálnak. Idetartozik a feltörekvő iparágak (például a MiC25ben felsorolt iparágak) GDP- és exportrészesedésének alakulása, az egyes „jövőiparágakon" belül Kína világpiaci részesedése, a szabadalmak száma, a $\mathrm{K}+\mathrm{F}$-beruházások (és azok GDP-aránya), a világ legnagyobb (és a legnagyobb technológiai) cégei között a kínai cégek száma, a technológiaorientált startupok és ezen belül az unikornisok száma, valamint néhány egyéb hagyományos innovációs input- és outputmutató. ${ }^{19} \mathrm{Ami}$ a digitális átalakulás területén elért eredményeket illeti, a technológia elterjedését számszerüsítő és szintén jól mérhető mutatószámok dominálnak, például a mobilfizetés és az e-kereskedelem, az ipari robotok, az önvezető technológia, a mesterségesintelligenciamegoldások belföldi elterjedésének méröszámai vagy a digitális infrastruktúra fejlettségét számszerüsítő mutatók. Tanulmányunkban bemutattunk ezek közül néhányat. Bár e mutatók használhatósága tekintetében helyenként már megfogalmaztuk kételyeinket, ${ }^{20}$ szögezzük le újra: ugyan e mutatók valóban azt tükrözik, hogy a kínai gazdaság bizonyos tekintetben közelít a fejlett tudásgazdaságok jellegzetességeihez, ezek önmagukban mégis csupán felszíni eredmények. A modernizációs pálya megváltozásáról, a - jobb híján - „innovációvezéreltként” leírt fejlődés jellegzetességeinek előtérbe kerüléséről reálisabb képet kaphatunk, ha megvizsgáljuk, milyen előrehaladás történt a másik csoportba tartozó sajátosságok területén.

2. A másik csoportba olyan tényezőket soroltunk, amelyek az előbbieknél sokszor nehezebben számszerüsíthetők, gyakran csupán általános kifejezésekkel írhatók le, ugyanakkor ezek a sajátosságok az előbbi csoport mutatóinál szorosabb összefüggést mutatnak a fejlett gazdaságokra jellemző, innovációvezérelt fejlődési pályával.

Az első ilyen sajátosság, hogy bár természetesen másutt kifejlesztett tudást is importálnak, a fejlesztéshez szükséges tudást és a müködtetéshez szükséges knowhow-t zömében helyben alkotják meg és fejlesztik folyamatosan tovább. Ez a fejlett tudásgazdaságokat jellemző sajátosság sokféle mutatóval közelíthető meg.

\footnotetext{
${ }^{19}$ Idetartozik például a tudományos publikációk száma, a kutatók és kutatóhelyek száma, a kutatásfejlesztésbe irányuló működőtőke-befektetések volumene.

${ }^{20}$ A torzítást többek között az okozza, hogy ezek a mutatók nem egyértelműen tükrözik a modernizációs stratégiaváltás eredményességét, ugyanis egyes inputmutatók (például a $\mathrm{K}+\mathrm{F}$-ráfordítások) hatékonysága és néhány outputmutató (például a szabadalmak) jelentősége, gazdasági hatása tekintetében nagy eltérések lehetnek (lásd még Szalavetz [2011]).
} 
Az egyik mutató a külföldi hozzáadott érték részesedésének csökkenése. A kínai adatokat a 12. ábrán mutatjuk be.

12. ábra

A külföldi hozzáadott érték részesedése a kínai exportból (százalék)

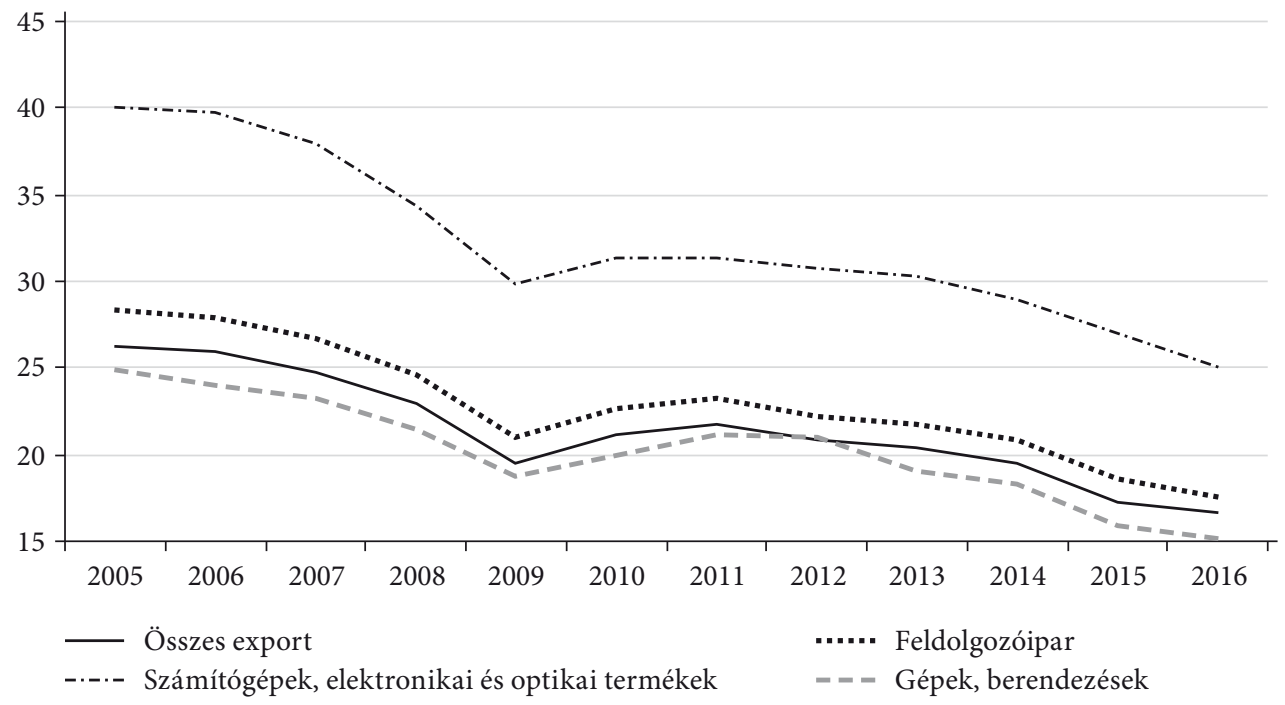

Forrás: OECD TiVA adatbázis adatai alapján saját szerkesztés.

A tudás lokalizációja területén elért fejlődést a kínai márkák számának és világpiaci jelentőségének növekedése is számszerűsíti. Ezt tükrözi a technológiaorientált startupok és unikornisok száma, valamint azoknak a gyorsan növekvő regionális (de leggyakrabban egy-egy metropoliszban összpontosuló) startupcsomópontoknak a száma és teljesítménye is, amelyek gyorsan növekvő, új technológiára szakosodó startupokat bocsátanak ki. ${ }^{21}$

A fejlett országokra jellemző második sajátosság, hogy az innováció diverzifikált, pontosabban a közepes jövedelmű országokra jellemző mértéknél kevésbé koncentrálódik meghatározott iparágakra, régiókra és/vagy meghatározott vállalati körre, vagyis nem csupán döntően a nagyvállalatok és a külföldi tulajdonú cégek körében van jelen. A technológiaorientált startupok száma, eredményei és az ehhez kapcsolódó egyéb területeken (startupcsomópontok, kockázatitőke-bevonás) elért kínai eredmények, sőt általános értelemben a vállalkozási teljesítmény korábban bemutatott átfogó és egyes területeken kiemelkedő javulása nem csupán a tudás lokalizációját, hanem az innováció „szétterülését”, koncentrációjának csökkenését is tükrözi. Ezek a jelenségek a „felszíni” mutatókkal bemutatottaknál mélyebb változásokra utalnak: a modernizációs stratégiaváltás első eredményeit tükrözik.

${ }^{21}$ A Startup Genome [2019] jelentése szerint Kínában három, a Szilícium-völgyhöz hasonló startupcsomópont található (Peking, Sanghaj és Hongkong), továbbá Hangcsou és Sencsen is jó úton van ahhoz, hogy bekerüljön a világ top 30 startupcsomópontja közé. 
Ezen a ponton hangsúlyoznunk kell, hogy mindez csupán annyit jelent, hogy már láthatók a változások első jelei. Ma és szerzőtársai [2019] kínai adatbázisokra, valamint az 500 legnagyobb, tőzsdén jegyzett kínai vállalat mérlegbeszámolóinak adataira építő elemzése azt mutatja, hogy földrajzi, regionális értelemben nincs szó szétterülésről: Kína innovációs teljesítménye a keleti part menti övezetekben koncentrálódik, sőt mint $L u$-Cao [2019] rámutat: a kiemelt metropoliszok fejlődése minimális mértékben sem gyürüzik át a környező városokéra. Az innováció iparági koncentrációjának csökkenése is éppen csak elindult: az innovációk döntő többsége még mindig a csúcstechnológiát megtestesítő feldolgozóiparban és a tudásintenzív szolgáltatásokban van jelen.

A fejlett országokra jellemző harmadik sajátosság az immateriális tőke jelentős súlya az összes beruházáson belül. Az immateriális tőkeállomány számszerüsítése érdekében nemzetközi statisztikai módszertani fejlesztések történtek (például Corrado és szerzőtársai [2005], Ilmakunnas-Piekkola [2014]), és az ökonometriai számítások rendre kimutatták az immateriális tőkefelhalmozás erőteljes és növekvő szerepét a fejlett országok növekedésének hajtóerői között (például Corrado és szerzőtársai [2009], Fukao és szerzőtársai [2009]).

Az országos szintü vizsgálatokba természetesen Kína is bekapcsolódott (például Hulten-Hao [2012], Li-Hou [2019], Yangés szerzőtársai [2018]). A kínai immateriális tőkefelhalmozás gyorsan bővülő irodalmának megállapításait két állítással foglalhatjuk össze. 1. Az immateriális tőkeállomány minden vállalati összetevője, tehát a vállalatszervezeti tőke (idetartozik a vállalatspecifikus emberi tőke, a márkaérték, az üzleti modell, a piaci pozíció), az informatikai tőke (például szoftverek és egyéb digitalizált információk, adatbázisok) és a technológiai tőke is látványosan nőtt az elmúlt évtizedben - bár Yang-Zhou [2017] input-output számításai szerint Kína még mindig erősen lemaradt a fejlett országoktól ebben a tekintetben. 2 . Az immateriális tőkeállomány növekedése megalapozza a termelékenység további erösödését, de rövid távon ezek a beruházások nem gyakorolnak erős, közvetlen pozitív hatást a gazdaság növekedésére.

Mielőtt következtetéseinkre rátérnénk, le kell szögeznünk, hogy a szóhasználat hasonlósága és néhány egyéb hasonlóság (a fejlesztés erőltetett üteme, a masszív beruházások alacsony hatékonysága - Ma és szerzőtársai [2019], Wei és szerzötársai [2017]) ellenére a digitális nagy ugrás nem hasonlítható össze rossz emlékủ elödjével, a Mao Ce-tung-féle „nagy ugrással” (ez utóbbiról lásd például Chan [2001]).

A szakirodalom és a statisztikák elemzése alapján megállapítható, hogy Kína látványos eredményeket ért el a „digitális nagy ugrásra” és a mesterséges intelligenciára alapozott gazdaságfejlesztési stratégiájával. A gazdaság fejlettségét tükröző elsődleges („felszíni”) mutatók történelmileg páratlanul rövid idő alatt kiemelkedő mértékben javultak, ami még annak ellenére is lenyügöző teljesítmény, hogy az elemzők többsége joggal hívta fel a figyelmet arra, hogy ezt az eredményt talán lassabban, de mindenképpen jóval kevesebb eröforrással, hatékonyabban is el lehetett volna érni (Hong és szerzőtársai [2016], Howell [2017], Wei és szerzőtársai [2017] ellentétes véleményt képvisel $H u$-Yongxu [2019]).

Nem csupán a „felszíni” mutatók tükrözik, hogy a kínai gazdaság a fejlett tudásgazdaságokhoz közelít: az utóbbi fél évtizedben egyre inkább láthatóvá vált, hogy 
kezdenek beérni az intenzív fejlődés érdekében tett extenzív erőfeszítések ${ }^{22}$ gyümölcsei. Felgyorsult a tudás lokalizációja és diverzifikációja, csökkent az innovációk koncentrációja, felhalmozódik és egyre jelentősebb növekedési hajtóerővé válik az immateriális tőkeállomány.

Látnunk kell azonban, hogy ez a közelítés azt jelenti, hogy Kína elöre halad(t) azon az úton, amelynek célja a fejlett tudásgazdaságokhoz történő valódi felzárkózás. Az előtte álló út - az eddigi látványos eredmények ellenére - továbbra is hosszú, ráadásul mozgó célponthoz igyekszik közelíteni.

Megállapíthatjuk, hogy a hazai innovációs képességnek a feltörekvő iparágakba és technológiákba irányuló, nagy volumenü beruházásokkal történő szisztematikus fejlesztése (a nagy belső piacra alapozva, az emberitőke-állomány fejlesztésével és vállalkozásösztönzéssel kísérve) a modernizációs stratégiaváltás megvalósítására igen, de a kínai gazdasági növekedés felgyorsítására már nem egyértelmüen alkalmas. A kínai gazdaság teljesítménymutatóit ma még jóval erőteljesebben határozzák meg a hagyományos, „tégla és habarcs” tételek (például az infrastrukturális beruházások, az új, exportorientált termelési kapacitások), mint az új növekedési mozgatórugók. Ráadásul a korábbiaknál erőforrás-hatékonyabb, nagyobb fajlagos hozzáadott értékü termelésre történő átállás jelentős strukturális veszteségeket okoz, ami kedvezőtlenül befolyásolja a növekedési mutatókat.

Alkalmas-e ez a stratégia arra, hogy Kína elkerülje a közepes jövedelmi csapdát? A válasz röviden az, hogy ez a stratégia és annak szisztematikus megvalósítása elengedhetetlen, de nem feltétlenül elégséges ennek a célnak az eléréséhez. Igaz, ha a „magas jövedelmü ország” státusát szüken értelmezzük, vagyis csupán az egy före jutó GNI meghatározott küszöbértékét vesszük alapul, Kína rövidesen és viszonylag könnyen bekerülhet ebbe a kategóriába. A kategóriaváltás jelentősége ugyanakkor kimerül abban, hogy ez az eredmény jól kommunikálható. Ha azonban a közepes jövedelmű ország státusának elhagyását úgy értelmezzük, hogy Kína fejlett tudásgazdasággá válik, e cél eléréséhez még hosszú évtizedek szisztematikus ipar- és technológiapolitikai erőfeszítéseire van szükség.

\section{Hivatkozások}

Ács Zoltán-Szerb LÁszló [2012]: Global Entrepreneurship and Development Index, 2012. Edward Elgar, Cheltenham, https://doi.org/10.4337/9781781001158.

Adler, G.-Duval, M. R. A.-Furceri, D.-Sinem, K.-Koloskova, K.-Poplawski-Ribeiro, M. [2017]: Gone with the headwinds: global productivity. International Monetary Fund, IMF Staff Discussion Note, No. 04. https://doi.org/10.5089/9781475589672.006.

Aiyar, S.-Duval, R.-Puy, D.-Wu, Y.-Zhang, L. [2013]: Growth Slowdowns and the MiddleIncome Trap. IMF Working Paper, No. 7. http://dx.doi.org/10.5089/9781484330647.001.

Amaglobeli, S.-Shi, W. [2016]: How to Assess Fiscal Implications of Demographic Shifts: A Granular Approach. IMF Fiscal Policy Notes, No. 2. https://doi.org/10. 5089/9781475536072.061.

${ }^{22} \mathrm{Ez}$ a furcsa szókapcsolat az önálló innovációs potenciál kiépítésére fordított páratlan volumenű beruházásokra utal. 
Baily, M. N.-Manyika, J.-Gupta, S. [2013]: US productivity growth: An optimistic perspective. International Productivity Monitor, Vol. 25. 3-12. o.

Bloom, D.-Canning, D.-Malaney, P. [2000]: Demographic Change and Economic Growth in Asia. Population and Development Review, Vol. 26. 257-290. o.

Bulman, D.-Eden, M.-Nguyen, H. [2014]: Transitioning from Low-Income Growth to High-Income Growth. Is There a Middle Income Trap? Policy Research Working Paper, No. 7104. World Bank, Washington, DC, https://doi.org/10.1596/1813-9450-7104.

Chan, A. L. [2001]: Mao's crusade: politics and policy implementation in China's great leap forward. Oxford University Press, Oxford.

Chang, L. [2016]: China outlines its latest Five Year Plan, called Internet Plus. Digital Trends, március 6. https://www.digitaltrends.com/web/china-internet-plus/.

Chenery, H. B.-Taylor, L. [1968]: Development patterns: Among countries and over time. Review of Economics and Statistics, Vol. 50. No. 4. 391-416. o. https://doi. org/10.2307/1926806.

Cheng, H.-JiA, J.-Li, D.-Li, H. [2019]: The rise of robots in China. Journal of Economic Perspectives, Vol. 33. No. 2. 71-88. o. https://doi.org/10.1257/jep.33.2.71.

CISTP [2018]: China AI Development Report 2018. China Institute for Science and Technology Policy at Tsinghua University, http://www.sppm.tsinghua.edu.cn/eWebEditor/UploadFile/ China_AI_development_report_2018.pdf.

Corrado, C. A.-Hulten, C. R.-Sichel, D. E. [2005]: Measuring Capital and Technology an Expanded Framework. Megjelent: Corrado, C.-Haltiwanger, J.-Sichel, D. E. (szerk.): Measuring Capital in the New Economy. University of Chicago Press, Chicago, 11-46. o. https:// doi.org/10.7208/chicago/9780226116174.003.0002.

Corrado, C.-Hulten, C.-Sichel, D. [2009]: Intangible capital and US economic growth. Review of Income and Wealth, Vol. 55. No. 3. 661-685. o. https://doi.org/10.1111/j.14754991.2009.00343.x.

Dedrick, J.-Kraemer, K. L.-Linden, G. [2010]: Who profits from innovation in global value chains?: a study of the iPod and notebook PCs. Industrial and Corporate Change, Vol. 19. No. 1. 81-116. o. https://doi.org/10.1093/icc/dtp032.

Dewan, S. [2018]: Wired for Work. Exploring the Nexus of Technology \& Jobs. Intergovernmental Group of Twenty-Four and Friedrich Ebert Stiftung Working Papers, https://www. g24.org/wp-content/uploads/2018/12/Sabina_Dewan_Wired_for_Work_FINAL.pdf.

Didier, T.-Ayhan Kose, M.-Ohnsorge, F.-Ye, L. S. [2016]: Slowdown in Emerging Markets: Rough Patch or Prolonged Weakness? Centre for Applied Macroeconomic Analysis, Australian National University, CAMA Working Paper, No. 1. https://doi.org/10.2139/ ssrn.2714651.

Dufrénot, G.-Rhouzlane, M. [2018]: Secular Stagnation: New Challenges for the Industrialized Countries in the 21st Century. https://halshs.archives-ouvertes.fr/halshs-01821669/ document.

EICHEngreen, B.-PARK, D.-Shin, K. [2013]: Growth slowdowns redux: new evidence on the middle-income trap. National Bureau of Economic Research, NBER Working Paper, No. 18673. https://doi.org/10.3386/w18673.

Eo, Y.-MorLey, J. [2018]: Why has the US economy stagnated since the Great Recession? https://doi.org/10.2139/ssrn.3077864.

Feenstra, R. C.-InklaAr, R.-Timmer, M. P. [2015]: The next generation of the Penn World Table. American Economic Review, Vol. 105. No. 10. 3150-3182. o. https://doi.org/10.1257/ aer.20130954. 
Felipe, J.-Abdon, A.-Kumar, U. [2012]: Tracking the Middle-income Trap: What Is It, Who Is in It, and Why? Levy Economics Institute Working Paper, No. 715. https://doi. org/10.2139/ssrn.2049330.

FukaO, K.-Miyagawa, T.-Mukai, K.-Shinoda, Y.-Tonogi, K. [2009]: Intangible investment in Japan: Measurement and contribution to economic growth. Review of Income and Wealth, Vol. 55. No. 3. 717-736. o. https://doi.org/10.1111/j.1475-4991.2009.00345.x.

GiLl, I.-Kharas, H. [2007]: An East Asian Renaissance. The World Bank, Washington, DC, https://doi.org/10.1596/978-0-8213-6747-6.

Glawe, L.-Wagner, H. [2017]: The People's Republic of China in the middle-income trap? ADBI Working Paper, No. 749.

Glawe, L.-Wagner, H. [2019]: China in the middle-income trap? China Economic Review, https://doi.org/10.1016/j.chieco.2019.01.003.

Gordon, R. J. [2014]: The demise of US economic growth: Restatement, rebuttal, and reflections. National Bureau of Economic Research Working Papers, No. 19895. https://doi. org/10.3386/w19895.

Greeven, M. J.-Yip, G. S.-WeI, W. [2019]: Understanding China's Next Wave of Innovation. MIT Sloan Management Review, Research Feature, február 7. http://ilp.mit.edu/media/ news_articles/smr/2019/60302.pdf.

Guillemette, Y.-Turner, D. [2018]: The Long View: Scenarios for the World Economy to 2060. OECD Economic Policy Papers, No. 22. OECD Publishing, Párizs, https://doi. org/10.1787/b4f4e03e-en.

Hong, J.-Feng, B.-Wu, Y.-WAng, L. [2016]: Do government grants promote innovation efficiency in China's high-tech industries? Technovation, Vol. 57-58. 4-13. o. https://doi. org/10.1016/j.technovation.2016.06.001.

Horowitz, M. C.-Allen, G. C.-Kania, E. B.-Scharre, P. [2018]: Strategic Competition in an Era of Artificial Intelligence. CNAS Center for a New American Security, Washington.

Howell, A. [2017]: Picking 'winners' in China: Do subsidies matter for indigenous innovation and firm productivity? China Economic Review, Vol. 44. 154-165. o. https://doi. org/10.1016/j.chieco.2017.04.005.

Hu, A. G.-YongXu, D. [2019]: Does government R\&D stimulate or crowd out firm R\&D spending? Evidence from Chinese manufacturing industries. Economics of Transition and Institutional Change, Vol. 27. No. 2. 497-518. o. https://doi.org/10.1111/ecot.12188.

Hulten, C. R.-Hao, J. X. [2012]: The role of intangible capital in the transformation and growth of the Chinese economy. National Bureau of Economic Research Working Papers, No. 18405. https://doi.org/10.3386/w18405.

Ilmakunnas, P.-PiekKola, H. [2014]: Intangible investment in people and productivity. Journal of Productivity Analysis, Vol. 41. No. 3. 443-456. o. https://doi.org/10.1007/s11123-013-0348-9.

JAYASOORIYA, S. P. [2017]: Growth slowdowns, middle-income trap, and demographic profile in South Asia. ADBI Working Paper, No. 736.

Jitsuchon, S. [2012]: Thailand in a Middle-Income Trap. TDRI Quarterly Review, Vol. 27. No. 2. 13-20. o.

KALDOR, N. [1967]: Strategic Factors in Economic Development. New York State School of Industrial and Labor Relations, Cornell University, Ithaca.

Ketchum, D.-Cheng, S. [2018]: Can 'one country, multiple systems' work for China's bay area development? South China Morning Post, február 13. https://www.scmp.com/ comment/insight-opinion/article/2133143/can-one-country-multiple-systems-workchinas-bay-area. 
Kharas, H.-Kohli, H. [2011]: What is the middle income trap, why do countries fall into it, and how can it be avoided? Global Journal of Emerging Market Economies, Vol. 3. No. 3. 281-289. o. https://doi.org/10.1177/097491011100300302.

Komlósi Éva-Szerb LÁszló-Ács J. Zoltán-OrtegA-Argilés, R. [2014]: A vállalkozási tevékenység regionális különbségei Magyarországon a regionális vállalkozási és fejlődési index alapján. Közgazdasági Szemle, 61. évf. 3. sz. 233-261. o.

Kuznets, S. [1966]: Modern Economic Growth. Yale University Press, New Haven, CT.

Kuznets, S. [1971]: Economic Growth of Nations. Total Output and Production Structure. Harvard University Press, Cambridge, MA.

Lewis, A. [1955]: The Theory of Economic Growth. Irwin, Homewood, IL.

LI, L. [2018]: China's manufacturing locus in 2025: With a comparison of "Made-in-China 2025" and "Industry 4.0". Technological Forecasting and Social Change, Vol. 135. 66-74. o. https://doi.org/10.1016/j.techfore.2017.05.028.

Li, S.-Candelon, F.-Reeves, M. [2018]: Lessons From China's Digital Battleground. MIT Sloan Management Review, https://sloanreview.mit.edu/article/lessons-from-chinasdigital-battleground/.

LI, X.-Hou, K. [2019]: R\&D based knowledge capital and future firm growth: Evidence from China's Growth Enterprise Market firms. Economic Modelling. Megjelenés alatt, https:// doi.org/10.1016/j.econmod.2019.07.005.

Lin, J. Y. [2019]: China's Growth Deceleration: Causes and Future Growth Prospect. Frontiers of Economics in China, Vol. 14. No. 1. 26-52. o.

Lu, Y.-CAO, K. [2019]: Spatial Analysis of Big Data Industrial Agglomeration and Development in China. Sustainability, Vol. 11. No. 6. 1783. o. https://doi.org/10.3390/su11061783.

Luohan Academy [2019]: Digital Technology and Inclusive Growth. Luohan Academy Report 2019. Executive Summary. https://gw.alipayobjects.com/os/antfincdn/DbLN6y Xw6H/Luohan_Academy-Report_2019_Executive_Summary.pdf.

MA, Z.-GAO, H.-YIN, W.-WEN, Z. [2019]: Innovation of Chinese listed enterprises: evaluation and policies. Megjelent: Song és szerzötársai [2017] 143-161. o. https://doi. $\operatorname{org} / 10.22459 /$ cet.2019.08.

Mason, A. (szerk.) [2001]: Population, Capital, and Labor. Population Change and Economic Development in East Asia. Challenges Met, Opportunities Seized. Stanford University Press, Stanford.

Mitchell, A. [2019]: Top 10 Chinese Startups to Watch in 2019. Noteworthy - The Journal Blog, június 29. https://blog.usejournal.com/top-10-chinese-startups-to-watch-in-201890690d7d6109.

Naughton, B. [2007]: The Chinese Economy: Transitions and Growth. MIT Press, Cambridge.

Nölke, A.-Ten Brink, T.-ClaAr, S.-May, C. [2015]: Domestic structures, foreign economic policies and global economic order: Implications from the rise of large emerging economies. European Journal of International Relations, Vol. 21. No. 3. 538-567. o. https://doi. org/10.1177/1354066114553682.

OECD [2019a]: OECD Compendium of Productivity Indicators. OECD Publishing, Párizs, https://doi.org/10.1787/b2774f97-en.

OECD [2019b]: OECD Economic Surveys: China. OECD Publishing, Párizs, https://doi. org/10.1787/eco_surveys-chn-2019-en.

Ohno, K. [2009]: Avoiding the middle income trap: Renovating industrial policy formulation in vietnam. ASEAN Economic Bulletin, Vol. 26. No. 1. 25-43. o. https://doi. org/10.1355/ae26-1c. 
Remes, J.-Mischke, J.-Krishnan, M. [2018]: Solving the productivity puzzle: The role of demand and the promise of digitization. International Productivity Monitor, Vol. 29. No. 35. 28-52. o. http://www.csls.ca/ipm/35/Remes-Mischke-Krishnan.pdf.

Rostow, W. W. [1959]: The Stages of Economic Growth. Economic History Review, Vol. 12. No. 1. 1-16. o. https://doi.org/10.1111/j.1468-0289.1959.tb01829.x.

Shi-Kupfer, K.-Ohlberg, M. [2019]: China's digital rise. Challenges for Europe. MERICS Papers on China, No. 7. Április, https://www.merics.org/sites/default/files/2019-04/ MPOC_No.7_ChinasDigitalRise_web_final.pdf.

Song, L.-Garnaut, R.-FAnG, C.-Johnston, L. (szerk.) [2017]: China’s New Sources of Economic Growth. Vol. 2. Human Capital, Innovation and Technological Change. ANU Press, Acton, https://doi.org/10.22459/cnseg.07.2017.

Startup Genome [2019]: Global Startup Ecosystem Report 2019. www.startupgenome.com.

State Council [2018]: Internet Plus: a life-changing initiative. State Council of the People's Republic of China, január 21. http://english.www.gov.cn/premier/news/2018/01/21/ content_281476021268046.htm.

Syverson, C. [2017]: Challenges to mismeasurement explanations for the US productivity slowdown. Journal of Economic Perspectives, Vol. 31. No. 2. 165-186. o. https://doi. org/10.1257/jep.31.2.165.

Szalavetz Andrea [2011]: Innovációvezérelt növekedés. Közgazdasági Szemle, 58. évf. 5. sz. 460-476. o.

Szalavetz Andrea [2017]: Industry 4.0 in 'factory economies'. Megjelent: Galgóczi Béla-Drahokoupil, J. (szerk.): Condemned to be Left Behind. Can Central and Eastern Europe Emerge from its Low-Wage Model? European Trade Union Institute, Brüsszel, 133-152. o.

Szalavetz Andrea [2019]: Mesterséges intelligencia és technológiavezérelt termelékenységemelkedés. Külgazdaság, 63. évf. 7-8. sz. 53-79. o.

Ten Brink, T. [2013]: Chinas Kapitalismus: Entstehung, Verlauf, Paradoxien / China’s Capitalism: Emergence, Trajectory, Paradoxes. Campus, Frankfurt-New York, NY.

Tно, T. V. [2013]: The Middle-Income Trap: Issues for Members of the Association of Southeast Asian Nations. Asian Development Bank, Manila, ADB Working Paper, No. 421. https://doi.org/10.2139/ssrn.2266239.

Tian, G. [2019]: Deceleration of China's Economic Growth: Causes and Countermeasures. Frontiers of Economics in China, Vol. 14. No. 1. 3-25. o.

WeI, S. J.-XIE, Z.-Zhang, X. [2017]: China's transition to a more innovative economy. Progress and challenges. Megjelent: Song és szerzötársai [2017] 173-211. o. https://doi. org/10.22459/cnseg.07.2017.08.

Woo, W. T. [2017]: Adjusting to the New Domestic Normal and the New International Normal: Supply-side Structural Reform 2.0. Megjelent: Song és szerzőtársai [2017] 89-113. o. https://doi.org/10.22459/cnseg.07.2017.05.

XU, X. [2019]: The Slowdown of China's Economic Growth in Terms of Statistics. Frontiers of Economics in China, Vol. 14. No. 1. 72-79. o.

YANG, S.-Zhou, Y. [2017]: Intangible Capital and China's Economic Growth: Evidence from Input-Output Tables. Megjelent: Song és szerzőtársai [2017] 147-169. o.

YANG, S.-Zhou, Y.-Song, L. [2018]: Determinants of Intangible Investment and Its Impacts on Firms' Productivity: Evidence from Chinese Private Manufacturing Firms. China \& World Economy, Vol. 26. No. 6. 1-26. o.

Yusuf, S.-Nabeshima, K. [2009]: Can Malaysia Escape The Middle-Income Trap: A Strategy For Penang. World Bank Policy Research Working Paper, No. 4971. https://doi. org/10.1596/1813-9450-4971. 
Zenglein, M. J.-Holzmann, A. [2019]: Evolving Made in China 2025. China's industrial policy in the quest for global tech leadership. MERICS Papers on China, No. 8. Július.

ZHAO, W. [2019]: China's innovation-driven growth and its emerging impact on global innovation. Megjelent: Wang, H.-Miao, L. (szerk.): Handbook on China and Globalization. Edward Elgar, Cheltenham, 175-185. o. https://doi.org/10.4337/9781785366086.00018.

Zhuang, J.-Vandenberg, P.-Huang, Y. [2012]: Growing Beyond the Low Cost Advantage. How the People's Republic of China can avoid the Middle Income Trap. Asian Development Bank, Manila.

\section{Közgazdasági Szemle MEGRENDELŐLAP}

Megrendelem a Közgazdasági Szemlét példányban, az alábbi címre:

Megrendelő neve:

Címe:

A kézbesítés helye:

Az előfizetési díjat csekken fizetem.

Az előfizetési díjat pénzintézeti átutalással egyenlítem ki.

Előfizetési díj egy évre: $26400 \mathrm{Ft} \square \quad$ fél évre: $13200 \mathrm{Ft}$

dátum aláírás

Megrendelhető levélben: Magyar Posta Rt., 1900 Budapest; faxon: 303-3440; e-mailben: hirlapelofizetes@posta.hu 